\title{
Value landscapes and their impact on public water policy preferences
}

Christopher Schulz ${ }^{\text {a, }}$, Julia Martin-Ortega ${ }^{c}$, Klaus Glenk ${ }^{b}$

${ }^{a}$ School of GeoSciences, The University of Edinburgh, Drummond Street, Edinburgh EH8 9XP, United Kingdom

${ }^{\mathrm{b}}$ Land Economy, Environment and Society Research Group, Scotland's Rural College (SRUC), Peter Wilson Building, Nicholas Kemmer Road, Edinburgh EH9 3FH, United Kingdom

' Sustainability Research Institute, School of Earth and Environment, University of Leeds, Leeds LS2 9JT, United Kingdom

Corresponding author contact information (present address)

Christopher Schulz

Department of Geography

University of Cambridge

Downing Place

Cambridge CB2 3EN

United Kingdom

E-mail: cs998@cam.ac.uk

Phone: +44 (0) 1223746983

\section{Acknowledgements}

This research was funded by a Scottish Government Hydro Nation Scholarship. The authors are grateful to all members of the general public in the Upper Paraguay River Basin who agreed to be interviewed for this study, to Cees van der Eijk, Todd K. Hartman and Jose Pina-Sánchez for advice on structural equation modelling, and to Vitale Joanoni Neto and Marcus Cruz for hosting Christopher Schulz at the Federal University of Mato Grosso (UFMT) during the fieldwork for this study. Insightful discussions with Antonio loris and Marcelo Guedes that informed the study design, as well as logistical support during the implementation of the survey, are gratefully acknowledged. 


\section{Highlights}

- First large-N study on values and public water policy preferences in Brazil

- Empirical identification of two alternative value landscapes (groups of values)

- Value landscapes relevant for determining people's water policy preferences

- Fundamental values relate equally to governance-related values and assigned values

- Findings may help to explain environment vs. development conflicts globally 


\title{
Value landscapes and their impact on public water policy preferences
}

\begin{abstract}
A growing body of research suggests that people's values may be important predictors of their preferences regarding water governance and policy. However, this assertion is rarely tested empirically. The present study summarises the results of a large-scale quantitative study on the link between public water policy preferences and people's values, based on data from a representative sample of the general population collected in a household survey in the Upper Paraguay River Basin, Mato Grosso, Brazil ( $n=1067)$. Structural equation modelling is applied to represent the clusters of values, or 'value landscapes', that shape attitudes and water policy preferences, in this case, for or against the construction of the highly controversial Paraguay-Paraná Waterway across the Pantanal wetland. Results demonstrate that opponents of the waterway share a value landscape composed of closely related self-transcendence values, democratic governance-related values, and ecological and cultural water values, whereas supporters hold self-enhancement values, economic governancerelated values, and economic water values. Beyond this individual case study and beyond water governance, our findings may explain the protracted nature of, and seeming impossibility to resolve, environmental conservation vs. economic development conflicts more broadly.
\end{abstract}

\section{Keywords}

environmental values; value landscapes; political legitimacy; water governance; development; agribusiness; Paraguay-Paraná Waterway; Pantanal; Mato Grosso; Brazil

\section{Introduction}

It has been argued that studying values can help to better understand water governance and water policy, may potentially contribute to mitigating conflicts in water governance, and help to assess the political legitimacy of water policy (Bjornlund et al. 2013; Glenk \& Fischer 2010; Groenfeldt 2013; Grotenbreg \& Altamirano 2017; Hermans et al. 2006; loris 2012; Pradhananga et al. 2017; Salvaggio et al. 2014; Sanderson et al. 2017; Schulz et al. 2017a). There are a number of alternative theoretical conceptualisations of values, typically delimited by disciplinary boundaries (Dietz et al. 2005; loris 2012; Lockwood 1999; Schulz et al. 2017a).

One of the many existing conceptualisations is associated with environmental and social psychology, where values are understood as abstract guiding principles (fundamental values) that may influence human decision-making, attitudes, and behaviour, such as e.g. biospheric values, which emphasise caring about the intrinsic value of nature and the environment and may be associated with proenvironmental behaviour (Dietz 2016; Fulton et al. 1996; Rokeach 1973; Schwartz et al. 2012; Steg 2016).

Alternatively, values may be assigned to objects and places (Brown 1984; Chan et al. 2012; Ives \& Kendal 2014; Lockwood 1999), for example water resources (Seymour et al. 2011), nowadays often conceptualized as water ecosystem services, e.g. water supply or hydroelectric power generation (Grizzetti et al. 2016; Hackbart et al. 2017; Martin-Ortega et al. 2015; Small et al. 2017). Assigning values in this way is common to a number of disciplines, including ecological and environmental 
economics, and human geography, among others (Brown 1984; Chan et al. 2012; Ives \& Kendal 2014; Lockwood 1999).

For the applied field of water governance, some scholars (Glenk \& Fischer 2010; Schulz et al. 2017a; Schulz 2018) have suggested to study a third category of values, i.e. governance-related values, which are those values that express desirable characteristics of water governance, e.g. efficiency or social justice. Such values are currently often the topic of normative work on good governance principles (Akhmouch \& Correia 2016; Lockwood et al. 2010; Mostert 2015).

There are relatively few attempts to systematically integrate these different branches of the environmental social science literature, hampered not least by the use of different terminologies and by misunderstandings that can result from the multitude of potential meanings of the term 'value' (Brown 1984; Lockwood 1999; Pascual et al. 2017; Tadaki et al. 2017). In this context, Schulz et al. (2017a) have proposed an interdisciplinary conceptual framework that describes the complex relationships between different types of values and their links with water governance metaphorically as 'value landscapes' (Schulz et al. 2017a, 2017b) that forms the theoretical basis for the present study.

The value landscapes metaphor serves as a short-hand reference for groups of values that are frequently connected to each other in people's minds, i.e. values that should be closely linked to each other cognitively, but less closely to other groups of values, e.g. 'economic efficiency' as a governancerelated value might be linked with 'hydro-electrical power production' as an assigned value and 'power' and 'achievement' as fundamental values (Schulz et al. 2017a). Thus, value landscapes simultaneously incorporate the abstract level of fundamental values and principles, the more concrete level of assigned values of water and the environment, as well as the level of values implicit in governance. The conceptual innovation of the Value Landscapes Approach lies in this simultaneous consideration of said three types of values (fundamental values; governance-related values; assigned values), their interrelations, and links to water governance, including water policy preferences, as further explained in section 2 .

The water policy case study investigated in this article is the controversy over the Paraguay-Paraná Waterway, a water infrastructure project that would engineer the Paraguay River of Mato Grosso, Brazil, to facilitate year-round aquatic transport with large barges, and to connect Brazil's interior with global shipping routes (ANTAQ 2013; Figueiredo et al. 2012; Hamilton 1999; UFPR/ITTI 2016). In many ways, this project represents a classical environmental conservation vs. economic development conflict, given that it would impact the biodiversity of the world's largest freshwater wetland, the Pantanal (Fearnside 2001; Gottgens et al. 2001; loris 2013; Junk et al. 2006), but is advocated to accelerate economic integration of South American countries (Gioia 1987; Pires \& da Silva 2009), as well as economic growth in Mato Grosso's agribusiness sector (ANTAQ 2013; Arévalo 2015).

To investigate the relationships between types of values and water policy preferences within the conceptual framework of the Value Landscapes Approach, we employ structural equation modelling (SEM). SEM is an established method to understand attitudes and behavioural intentions in the context of applied social and environmental psychological studies (see e.g. Kaida \& Kaida 2016; Rahnama \& Rajabpour 2017; Shin et al. 2017; Toma et al. 2011) and one that allows to uncover complex relationships between latent constructs such as values (Garson 2015; Kline 2011).

With regard to water-related issues, a number of studies have focussed specifically on understanding psychological factors motivating support for water conservation and protection behaviour using SEM. These include beliefs and worldviews (Corral-Verdugo et al. 2008), attitudes and awareness (Cooper 2017; Floress et al. 2017; Yazdanpanah et al. 2014), perceptions (Hurlimann et al. 2008; Tang et al. 
2015; Yazdanpanah et al. 2014), perceived behavioural control and norms (Cooper 2017; Yazdanpanah et al. 2014), as well as people's values (Pradhananga et al. 2017), within theoretical frameworks including modifications of the Theory of Planned Behaviour (Ajzen 1985, 1991), Values-Beliefs-Norms Theory (Dietz 2016; Stern et al. 1999), or of the Cognitive Hierarchy model (Fulton et al. 1996; Homer \& Kahle 1988; Vaske \& Donnelly 1999).

Pradhananga et al.'s (2017) integrated moral obligation model, for example, highlights the positive association of collectivistic values (i.e. prioritising group goals over personal goals, and defining 'self' primarily as part of a group) and biospheric-altruistic values (i.e. of caring about the environment for its own sake as well as for improved human welfare) with people's norms (e.g. "I feel a personal obligation to use conservation practices on my land/property."; Pradhananga et al. 2017: 217) regarding water conservation behaviour. However, beyond the specific issue of water conservation there is a paucity of empirical evidence on the link between values and water policy preferences of the general public. An exception is Glenk and Fischer (2010), who investigated links between fundamental and governance-related values, beliefs, attitudes, and willingness to pay for flood mitigation.

The present study makes an empirical contribution to the interdisciplinary literature on values, water governance, and water policy by presenting the first attempt to test the aforementioned Value Landscapes Approach using quantitative methods. It is also the first large-scale study on people's values and public water policy preferences in Latin America. It builds on previous qualitative research on the value landscapes of major stakeholders from water-related sectors in the area (Schulz et al. 2017b), seeks to operationalise value landscapes for quantitative survey research, as well as to test their impact on water policy preferences using SEM techniques, based on survey data collected in a representative household survey in the Upper Paraguay River Basin, Mato Grosso, between April and June 2016. This article thus shows how the framework can be operationalised, and demonstrates its real-world relevance of providing a better understanding of water-related conflicts, and eventually of pathways for their resolution. By incorporating concepts from a wide range of literatures and disciplines, we also seek to contribute to interdisciplinary scholarship in general, despite the challenges associated with combining thoughts from various research traditions that may have different epistemological backgrounds and terminologies (Lockwood 1999; Norton 2017; Pascual et al. 2017).

\section{The Value Landscapes Approach: Conceptual overview}

The Value Landscapes Approach was introduced by Schulz et al. (2017a, 2017b) and refers to a conceptual framework that aims at 'mapping' people's values with the objective of achieving a better understanding of their positions and preferences in water governance, including in situations of conflict. The purpose of the Value Landscapes Approach is to systematise our understanding of the role of values in water governance from an interdisciplinary perspective. The metaphor of 'value landscapes' for groups of closely related values does not refer to actual geographical landscapes, but cognitive landscapes of values that are related in people's minds, inspired by the fact that landscapes are typically defined by the features of connectivity and (physical) closeness of various elements, e.g. in ecology (Taylor et al. 1993).

Justification for the introduction of a new conceptual framework were i) that many existing studies apply a single theoretical, monodisciplinary perspective, despite potential additional insights that may arise from combining the findings of multiple disciplines (see also Hermans et al. 2006); and ii) that 
existing interdisciplinary studies that argue for the need to take values into account for better water governance (e.g. van Schie et al. 2011) have paid limited attention to clearly distinguishing value types. For example, some authors may treat diverse values such as 'equity' or 'economic water values' as if they belonged into one single category of 'values', despite considerable differences in scope and nature of these values, which could be taken into account by distinguishing between fundamental, governance-related, and assigned values (Schulz et al. 2017a).

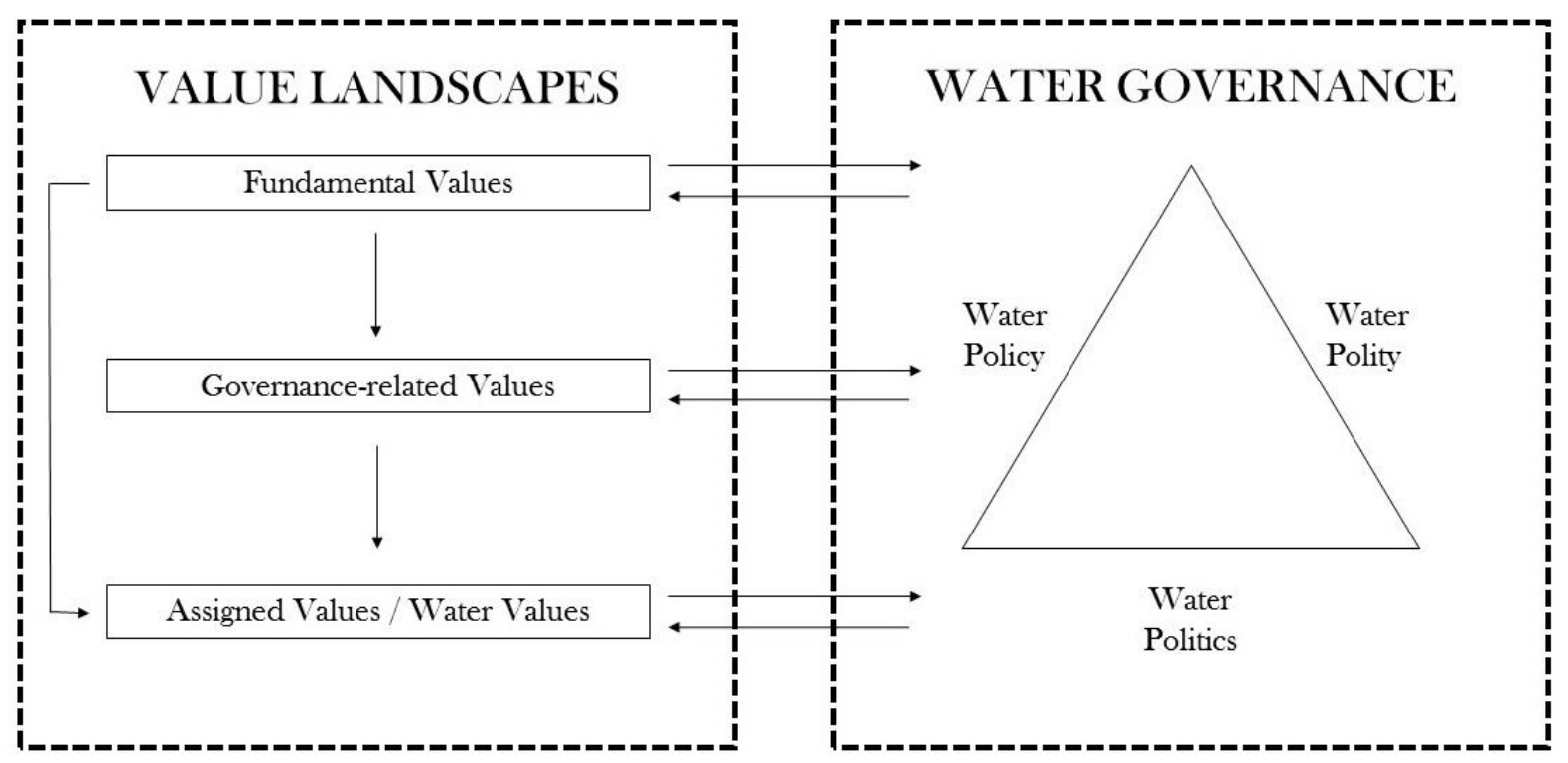

Figure 1: Schematic overview of the Value Landscapes Approach (adapted from Schulz et al. 2017a); arrows represent theoretically expected relationships of influence between variables

The Value Landscapes Approach brings together these three types of values (fundamental, governance-related, and assigned values), as well as their interrelationships and impacts on water governance and vice versa (see Figure 1). Arrows in Figure 1 represent theoretically-expected influence of some kind, i.e. the universally relevant fundamental values are expected to influence the more concrete governance-related values and assigned values / water values of people, but not vice versa (see also Brown 1984; Glenk \& Fischer 2010; Seymour et al. 2010). For example, people who prioritise 'universalism' as a fundamental value may also favour 'social justice' as a governance-related value and 'ecological values of water' as an assigned value, but we would not normally assume that a preference for ecological water values is the more general cause of prioritising fundamental values; and the concrete context of water governance in a given place and time may also impact on people's values, as experimental evidence shows that interacting within market institutions may erode moral values, for example (Falk \& Szech 2013). Similarly, one could expect an increased concern for the governance-related value of 'social justice' in a situation where a concrete water governance project would have strong negative impacts on vulnerable minorities. Here, our focus lies on the impact of values on water policy preferences, however.

The definition of water governance underpinning the Value Landscapes Approach is inspired by Treib et al.'s (2007) more general definition of governance as the combination of i) water polity (the institutional framework); ii) water politics (power relations between political actors); and iii) water policy (the mechanisms and instruments used to achieve certain outcomes). While the Value Landscapes Approach covers all three elements of water governance from a theoretical point of view, the present case study will focus on water policy, which we found most suitable for application within a survey with members of the general public. 
Based on insights from various disciplines, but especially ecological economics, the Value Landscapes Approach i) assumes a strong interconnectedness between water governance and values; ii) analyses values at different levels of abstraction, with influence from more abstract to more concrete values; iii) is based on the idea of value pluralism as an empirical reality that can be studied (Schulz et al. 2017a), i.e., it does not seek to translate values into one ultimate category (Martinez-Alier et al. 1998). Moreover, two broad hypotheses follow from this conceptual framework: i) if we know people's values in a given time and location, this may help to understand their preferences and behaviour in water governance; and ii) if we compare values expressed by actual water governance (e.g. a specific water policy with an implicit value content) with values held by members of the general public (especially governance-related and assigned values), we can assess the political legitimacy of existing water governance in a given time and location (Schulz et al. 2017b). While the Value Landscapes Approach was developed in the context of water governance, it could conceivably be adapted for the analysis of other fields of environmental governance more generally.

The Value Landscapes Approach shares some features with other existing conceptual frameworks. While a full discussion of commonalities and differences would be beyond the scope of the present paper, it should be noted that the Value Landscapes Approach's emphasis on identifying values at different levels of abstraction has similarities with the Cognitive Hierarchy Model (Fulton et al. 1996; Homer \& Kahle 1988; Vaske \& Donnelly 1999), Values-Beliefs-Norms Theory (Dietz 2016; Stern et al. 1999), as well as the Advocacy Coalition Framework (Sabatier 1988; Sabatier \& Weible 2007), which are all based on the analysis of a number of constructs at varying levels of abstraction that are to some degree causally related.

As opposed to the social psychological Cognitive Hierarchy Model and Values-Beliefs-Norms Theory, the Value Landscapes Approach has an explicit interdisciplinary focus that aims to integrate various value concepts from environmental and social psychology and beyond, given the centrality of the concept of value in disciplines such as ecological and environmental economics, human geography, and many others (see details below). Furthermore, it does not aim to represent an exhaustive model of human behaviour which is common to social psychological frameworks, but rather 'zooms in' on the concept(s) of values, and their relationship with governance.

Unlike the Advocacy Coalition Framework, the Value Landscapes Approach aims to understand interlinkages between values and governance as they exist in people's minds in general, beyond those specific actors that might have the opportunity to directly influence policy in their field (as part of an 'advocacy coalition'). In line with Henry and Dietz (2012: 251), it should be noted that despite their common focus on environmental cognition, the various conceptual frameworks listed here should be seen as complementary rather than competing, given that they aim to explain "different phenomena in different contexts".

\subsection{Fundamental values}

The concept of fundamental values has its origin in social psychological theory; these values are generally defined as abstract goals and principles that guide people's decision-making across situations (Dietz 2016; Fulton et al. 1996; Rokeach 1973; Schwartz 1992; Schwartz et al. 2012; Steg \& de Groot 2012; Steg 2016). The label 'fundamental values' is taken from Fulton et al. (1996), but numerous alternative terms exist that roughly fit the same definition, such as 'basic individual values' (Schwartz et al. 2012), 'terminal values' (Rokeach 1973), or 'transcendental values' (Raymond \& Kenter 2016). 
One of the most popular theoretical frameworks for fundamental values is Schwartz' theory of basic individual values (Schwartz 1992; Schwartz et al. 2012), which in turn was inspired by earlier work of Rokeach (1973; Schwartz \& Bilsky 1987). In its original form, Schwartz $(1992,1994)$ proposed the existence of ten basic values that are universally recognised among humans across cultures, only varying in the relative importance given to them by different people across different situations. These values are particularly salient in situations of value conflict, i.e. decision-making situations where two alternative choices would reinforce different or opposing values (Schwartz 1992, 1994).

The ten fundamental values are universalism, benevolence, conformity, tradition, security, achievement, power, hedonism, stimulation, and self-determination, arranged in a circular structure that can be subsumed under two broad pairs of opposing higher-order dimensions (self-enhancement vs. self-transcendence and openness to change vs. conservation), which broadly translate into concern about oneself vs. concern for others, and a preference for novelty and innovation vs. a preference for keeping the status quo via order, self-restraint and traditions (Schwartz 1992, 1994).

While Schwartz and Boehnke (2004) note that these higher-order dimensions are but one of many possibilities to classify the ten basic values, a large number of empirical studies have found that selftranscendence values tend to be positively correlated with pro-environmental behaviour, norms, and attitudes, whereas self-enhancement values tend to be negatively correlated (Evans et al. 2013; Kilbourne et al. 2005; Schultz et al. 2005; Steg \& de Groot 2012). Considerably less consistent empirical evidence has been found for a relationship between pro-environmental behaviour and the dimensions of openness to change vs. conservation (but see Poortinga et al. 2004), although from a theoretical point of view one can easily construct such hypotheses, e.g. assuming that political conservatism goes along with reduced concern for the environment (Dietz 2016).

In the applied field of environmental psychology, the subset of fundamental values that are strongly correlated with environmental concern and pro-environmental behaviour in modified versions of the Schwartz value theory $(1992,1994)$, such as biospheric or altruistic values (i.e. of caring about the environment for its own sake as well as for improved human welfare) (Steg, Perlaviciute et al. 2014; Stern et al. 1998) are often referred to as 'environmental values' (Dietz 2016; Steg \& de Groot 2012). Thus, in environmental psychology, 'environmental values' typically stands for (personally held) 'values and abstract goals that inform pro-environmental behaviour, norms, and attitudes'. However, it is important to note that the same term can also mean 'values of the environment', i.e. assigned values (see section 2.3), which is a typical use in disciplines such as ecological economics or human geography, or where environmental valuation is concerned (Arias-Arévalo et al. 2017; Norton \& Steinemann 2001; Seymour et al. 2011; Spash \& Vatn 2006; Tadaki et al. 2017). This polysemy (i.e. multiple related meanings of the same words) may cause some confusion, which we avoid here by using the conceptual framework proposed by Schulz et al. (2017a).

Analogous to biospheric and altruistic values as elements of the self-transcendence dimension, a number of individual fundamental values have been identified in the literature that tend to correlate negatively with pro-environmental behaviour, norms, and attitudes. These are egoistic and hedonic values (i.e. a concern about one's personal resources; or for improving one's feelings and reducing effort), which fall into the broader dimension of self-enhancement (Steg, Bolderdijk et al. 2014; Steg \& de Groot 2012), although hedonic values are also sometimes categorised as pertaining to the openness to change dimension (Dietz 2016; Schwartz 1992, 1994).

From the perspective of the practitioner in environmental management, research in environmental psychology suggests that better knowledge of environmental values can contribute to better design of incentives for pro-environmental behaviour (Crompton et al. 2010), including environmental policy. 
For example, the recently proposed Integrated Framework for Encouraging Pro-environmental behaviour' (IFEP) outlines multiple pathways for encouraging pro-environmental behaviour, such as the activation of biospheric values via situational cues or the reduction of perceived costs associated with such behaviour (Steg, Bolderdijk et al. 2014). Given the relatively stable nature of fundamental values across an individual's lifetime (and across generations), their activation via situational cues (e.g. in the context of marketing or information campaigns) seems indeed a much more viable strategy than simply aiming to 'change' values in general.

Value change involves timescales of generations and is thus difficult to control (Manfredo et al. 2017a, 2017b), although Ives and Fischer (2017) suggest that short-term value change is sometimes possible, and that, even if difficult and slow, intentional value change should remain an important priority e.g. for conservationists. Also, it is important to remember that people may hold multiple and competing values that may contradict each other (Schwartz 1992, 1994). Yet, 'value activation' strategies will be more successful with individuals who hold stronger pro-environmental values than others in the first place (Steg, Bolderdijk et al. 2014; Steg \& de Groot 2012). In any case, all cited studies emphasise the real-world relevance of research on people's (environmental) values in the context of concrete decision-making situations, as well as their relevance for understanding environmental cognition more broadly (Dietz 2016; Steg 2016).

\subsection{Governance-related values}

In the Value Landscapes Approach, governance-related values are defined as idealised characteristics or properties of water governance that are expressed as desirable by individuals and groups (Schulz et al. 2017a). The concept is less established as a distinct analytical category than fundamental values (Schulz 2018), although governance-related values themselves, such as equity or sustainability, have been the subject of philosophical and normative debates for centuries (see e.g. Du Pisani 2006; Young 1994). They also frequently appear in the general public administration literature, where a separate body of research on the topic is consolidating (Beck Jørgensen \& Bozeman 2007; de Graaf et al. 2016; Rutgers 2015; Tsanga Tabi \& Verdon 2015).

Applied to the field of water governance, studies often evaluate the degree of various governancerelated values such as sustainability (e.g. Antunes et al. 2009; Iribarnegaray \& Seghezzo 2012; Kuzdas et al. 2014; Milman \& Short 2008), legitimacy, efficiency and effectiveness (e.g. Lieberherr et al. 2012; Moss \& Newig 2010; van Meerkerk et al. 2015) or social justice (e.g. Lukasiewicz et al. 2013; Patrick 2014; Perreault 2014) associated with different governance options. Many of these studies develop sophisticated systems of indicators aimed at measuring and evaluating the level of realisation of such governance-related values in practice (see e.g. van Leeuwen et al. 2012 for a list of 24 indicators measuring the sustainability of urban water governance). In their level of detail, these indicator systems go far beyond the general definition of each respective value, e.g. of sustainability as the possibility for a process to continue within long, potentially indefinite time-scales (Johnston et al. 2007) or the notion of safeguarding natural resources for future generations (Daly 1990). Yet by looking at individual values only, they fail to consider inevitable trade-offs and/or conflicts between various governance-related values (de Graaf et al. 2016; Grotenbreg \& Altamirano 2017), such as between social justice and economic efficiency. Nevertheless, the existence of such a large body of literature on individual governance-related values points to high levels of interest in this specific category, and provides additional justification for the inclusion of this type of values into the conceptual framework underpinning our empirical analysis. 
Governance-related values may thus serve as abstract guiding principles in decision-making in water governance, or represent properties of water governance that may or may not have been realised yet. They are different from fundamental values as they are located at the intersection of internal, abstract goals, and external values assigned to elements of governance (such as a concrete policy), taking a middle position between fundamental and assigned values in the Value Landscapes Approach (Schulz et al. 2017a). Sustainability or social justice are both abstract goals as well as properties assigned to elements of governance.

Holders of governance-related values are not only actors and stakeholders within water governance, but also members of the general public (Glenk \& Fischer 2010; Schulz et al. 2017a; Schulz 2018). Despite numerous case studies on individual values as cited above, and a number of conceptual overview papers on natural resource governance principles (Akhmouch \& Correia 2016; Kooiman \& Jentoft 2009; Lockwood et al. 2010; Moreno Pires et al. 2017; Mostert 2015), Glenk and Fischer (2010) note a lack of quantitative research on governance-related values, especially in the environmental economics and psychology literatures. In the absence of an established comprehensive governancerelated values theory and associated measurement instruments, it is thus left to individual researchers to define their own set of governance-related values to be studied on a case-by-case basis (Schulz 2018).

\subsection{Assigned values / water values}

The concept of assigned values refers to the concrete values that people attach to the environment, environmental resources, landscapes and places (Brown 1984; Chan et al. 2012; Ives \& Kendal 2014; Lockwood 1999; Schulz et al. 2017a; Seymour et al. 2010). As such, this category of values is the most prevalent type in the environmental valuation literature, although terminologies may vary widely, with the most common conceptualization currently used being the ecosystem services framework (Grizzetti et al. 2016; Hackbart et al. 2017; Martin-Ortega et al. 2015; Small et al. 2017). Here we prefer to use the more open-ended term 'assigned values' as opposed to the more prescriptive term 'ecosystem services', which is associated with a particular normative vision of environmental management and human-nature relationships (Schröter et al. 2014) that may not necessarily match with the normative vision that the average person subscribes to (Braito et al. 2017).

The term 'water values' simply stands for assigned values of water resources. It may refer to their value for irrigation, human consumption, bathing, navigation, or their role in sustaining ecosystems, as well as to more intangible values such as cultural, aesthetic and spiritual values. It is used as a shorthand reference for such assigned values in a significant part of the literature, especially in human geography and related areas (see e.g. Barber \& Jackson 2011; Bark et al. 2011; Berry et al. 2018; Euzen \& Morehouse 2011; Gibbs 2010; loris 2012), but also in environmental economics (e.g. Bjornlund \& O'Callaghan 2005; Saliba et al. 1987). Similar terms exist for other important environmental resources, e.g. 'forest values' (Bengston 1994; Brown 2013; Brown \& Reed 2000; Manning et al. 1999; McIntyre et al. 2008). Assigned values have been measured using a wide range of methods from focus group research to survey approaches, but due to their variability and context-specific nature (which is typically emphasised by human geographers, e.g. Gibbs 2010; loris 2012), their classification and measurement is usually customised to fit the specific research context at hand (Ives \& Kendal 2014; Seymour et al. 2010).

Lockwood (1999) noted that assigned values are conceptually close to environmental attitudes (i.e. psychological tendencies to favour or disfavour certain attitude objects) in the environmental 
psychology literature, e.g. where attitudes towards specific 'environmental objects' such as hazardous waste dumps are concerned (Stern et al. 1995), not least because both assigned values and environmental attitudes are comparatively more concrete than fundamental values (i.e. abstract transsituational goals), and relate to external objects (Lockwood 1999). Nevertheless, here we follow Dietz et al. (2005) who suggest that attitudes are far more specific than values, giving the example of the (assigned) value of 'wilderness', and the attitude of 'opposing oil development in a wildlife refuge'. We also prefer the terminology of 'values' to that of 'attitudes', given that values are generally seen as more stable than attitudes, which in turn may change more easily (Dietz et al. 2005; Homer \& Kahle 1988; Shin et al. 2017).

Another related concept are 'beliefs', which have been defined as "facts as an individual perceives them" (Dietz et al. 2005: 346). Yet, as Schwartz (1992) notes, all (fundamental) values are also beliefs; and in the same way, all assigned values are also beliefs about the particular qualitative importance of an environmental resource (e.g. 'water resources are a source of fish', or of cultural value), which typically go along with a quantitative assessment of the resource's relative importance in comparison with other assigned values (e.g. 'the ecological value of water is more important than its aesthetic value') (Bengston 1994; Ives \& Kendal 2014; McIntyre et al. 2008; Seymour et al. 2010). While all assigned values are beliefs, not all beliefs are assigned values, so we prefer to use the term 'assigned value' throughout our analysis, which is more parsimonious and can avoid confusion with beliefs beyond the realm of values. This is not to say that we oppose the simultaneous investigation of values and beliefs-beyond-values, which is established practice e.g. in values-beliefs-norms theory (Dietz 2016; Stern et al. 1999).

\section{Applying the Value Landscapes Approach to the conflict over the Paraguay-Paraná Waterway, Mato Grosso, Brazil}

In this article, we apply the Value Landscapes Approach to the case study of a conflict over the construction of the Paraguay-Paraná Waterway (Hidrovia Paraguai-Paraná) in the state of Mato Grosso, Brazil. This is a typical environmental conservation vs. economic development conflict. The waterway is part of a strategic national plan for Brazil's inland navigation infrastructure and has the objective of facilitating year-round aquatic transport and the export of agricultural products such as soybeans and cotton from Mato Grosso to world markets (ANTAQ 2013). This would reduce transport costs significantly, and likely further fuel the expansion of soybean production in Mato Grosso (Fearnside 2001), already Brazil's leading producer (Arvor et al. 2018; loris 2016), with strong trade links to China (Lathuillière et al. 2014; Peine 2013). While the full waterway extends over $3442 \mathrm{~km}$ from Cáceres, Mato Grosso, Brazil, to the port of Nueva Palmira in Uruguay, crossing Paraguayan and Argentinean territory further downstream, the main controversy concerns the upriver segment on the Paraguay River in Mato Grosso, near Cáceres, which would run across the Pantanal wetland (da Silva et al. 2004; Figueiredo et al. 2012; Leão et al. 2013; Schulz et al. 2017b).

The Pantanal is often considered a global natural heritage, recognised e.g. by UNESCO or the Ramsar Convention, due to its status as an important refuge for endangered biodiversity (Calheiros et al. 2012; loris 2013; Junk et al. 2006). Implementing the waterway there would require major engineering works, such as dredging of shallow sections, removal of rocks, and straightening of curves (Hamilton 1999), which would impact on the hydrology and ecology of the Pantanal, including its characteristic 'flood pulse', with associated repercussions for local biodiversity, flood protection downstream, as well as local people's livelihoods (da Silva et al. 2004; Gottgens et al. 2001; Junk et al. 2006). As of 
2016, the project has passed a technical, economic, and environmental impact assessment (UFPR/ITTI 2016), but construction has not yet started, likely due to Brazil's ongoing political and economic crisis.

In a previous study, which laid the foundation for the present study, Schulz et al. (2017b) investigated the controversy over the Paraguay-Paraná Waterway using qualitative research techniques and focussing exclusively on professionals from water-related sectors in the state of Mato Grosso, rather than members of the general public, as is done here. The waterway is chiefly supported by the state government of Mato Grosso and the local agribusiness sector, and opposed by many environmentalists and fishermen who are concerned about impacts on biodiversity and fish stocks. A comparison of the values expressed by supporters of the waterway in the interviews with the values of those opposed suggested that among relevant stakeholders, support or opposition to the project went along with two very different value landscapes.

One value landscape consisted of a cluster of governance-related values such as efficiency, pragmatism, and order (in the sense of legal certainty, security, and the ability to plan more generally), which relate well to a general vision of Mato Grosso as a place of strong economic development and growth. These governance-related values were complemented with assigned values such as navigation, agriculture, tourism, and aquaculture, i.e. mostly economic water values. Values of this first value landscape were typically expressed by supporters of the waterway, especially representatives of the agribusiness sector. A second value landscape emerged with an alternative focus on governance-related values such as equity, social justice, conservation/tradition and solidarity, and assigned values mostly related to culture, such as subsistence fishing, traditional festivities along the rivers, aesthetic values, as well as ecological values of water. This value landscape was closely associated with opposition to the waterway and typically found among traditional fishermen in the Pantanal, as well as NGO activists and academics opposed to the project (Schulz et al. 2017b).

Thus, in line with the Value Landscapes Approach and the previous qualitative work of Schulz et al. (2017a, 2017b), in the present study we specifically aim to test the following two broad hypotheses:

H1: We can identify people's value landscapes operationalised as statistically identifiable relationships among the three different types of values (fundamental values, governance-related values, and assigned values), with fundamental values being the most abstract construct 'predicting' both governance-related values and assigned values.

The present study thus serves to test whether the hypothetical relations of influence outlined in the Value Landscapes Approach (visualised by the arrows on the left side of Figure 1) can indeed be identified empirically. Here the various types of values are operationalised via survey statements, with survey results then feeding into the design of a structural equation model (see sections 4 and 5 below). If such a structural equation model cannot be rejected, this could be seen as a form of empirical evidence and validation of the many different conceptual considerations that fed into the development of the Value Landscapes Approach. While a 'cascade' from more abstract concepts influencing more concrete concepts that people subscribe to is the basis of many theoretical frameworks (see e.g. Brown 1984; Glenk \& Fischer 2010; Homer \& Kahle 1988; Lockwood 1999; Seymour et al. 2010; Stern et al. 1999), no previous empirical evidence exists of the interrelatedness of fundamental, governance-related, and assigned values simultaneously. One study has investigated the link between fundamental and governance-related values (Glenk \& Fischer 2010), while there is some limited evidence of systematic links between fundamental values and assigned values (e.g. Hicks et al. 2015; van Riper \& Kyle 2014), but not between all three value types at once. 
Hicks et al. (2015) suggested that assigned values (referred to as ecosystem services in their study) can be directly associated with certain fundamental value domains (e.g. a preference for fish as an assigned value/provisioning service of a marine ecosystem is an expression of the fundamental value dimension of self-enhancement), which is in line with our conceptual framework; however, the study relied on the researchers to 'match' assigned values with corresponding fundamental values based on qualitative interview transcripts, whereas our study is using more established psychometric measurement instruments to elicit fundamental values (although admittedly such statistical approaches are less suited to detect individual outliers), and the links with further value categories are based on statistical evidence, rather than manual coding.

Van Riper and Kyle (2014), in turn, compared how people holding strong pro-environmental fundamental values identified various assigned values in a specific geographical area as opposed to more neutral research participants, using Public Participation Geographical Information System (PPGIS) methods (Sieber 2006) and a Social Values for Ecosystem Services (SolVES) mapping application (Sherrouse et al. 2011). The study demonstrated that those with stronger pro-environmental fundamental values gave much higher importance to various assigned values related to environmentalism, such as the assigned value of biodiversity, visualised in strikingly different maps of assigned values generated by pro-environmentalists' and a more neutral group's answers. These findings are in line with our conceptual framework, but again, our method of analysis is different. Also, neither van Riper and Kyle (2014) nor Hicks et al. (2015) considered governance-related values as a separate category of relevance to water governance / environmental governance more generally.

H2: There is a measurable impact of people's value landscapes on their water policy preferences.

Beyond understanding interrelations between values, we also aim to test the hypothesis that people's values influence their preferences in water governance (in this case, their water policy preferences), which follows from the various conceptual considerations on which the Value Landscapes Approach is based (as visualised by the arrows linking value landscapes and water governance in the middle of Figure 1).

This is a relevant hypothesis for multiple reasons; it enhances the real-world relevance of values research, given the applied nature of water governance, and further validates the idea that values are deeply embedded and connected to society and culture in multiple ways (Manfredo et al. 2017a), including in water governance (Groenfeldt 2013); it would demonstrate that values matter for water policy preferences, as opposed to other variables such as interests, which are defined as needs or desires for resources such as time, space, money or natural resources (Kouzakova et al. 2012), which one could expect to have played a larger role e.g. for the stakeholders interviewed by Schulz et al. (2017b). This is especially significant considering that conflicts about values (as opposed to mere material interests) are more likely to turn emotional or escalate (Kouzakova et al. 2012), which makes them much more difficult to resolve (Harinck \& Druckman 2017; Illes et al. 2014). Furthermore, measuring the impact of people's value landscapes on their water policy preferences with statistical methods and survey data from members of the general public as opposed to stakeholders is also important given that people may express different values in their capacity as group representatives (e.g. of a certain institution), as opposed to when consulted as private citizens (Cramer et al. 1993; Manfredo et al. 2017a).

\section{Methodological approach}

\subsection{Structural equation modelling}


Structural equation modelling (SEM) is a statistical technique that allows empirical testing of complex theoretical relationships between multiple variables, including latent variables such as people's values. Specifically, SEM studies typically combine path analysis (to test hypothesised causal structures between variables) and confirmatory factor analysis (to measure latent variables using several observed indicators) (Garson 2015; Kline 2011). As mentioned earlier, it is an established tool for the statistical analysis of underlying motivations for people's preferences and behaviour (e.g. Glenk \& Fischer 2010; Pradhananga et al. 2017; Toma et al. 2011; Yazdanpanah et al. 2014) and thus very suitable for the analysis of value landscapes and their impact on water policy preferences.

\subsection{The sample}

Our structural equation model relies on survey data collected among members of the general public $(n=1067)$ in the Upper Paraguay River Basin in Mato Grosso between April and June 2016 with the help of trained local interviewers. The Paraguay-Paraná Waterway would be constructed in this hydrographic area, which also encompasses large parts of the Pantanal wetland as well as major population centres of Mato Grosso, such as the state capital Cuiabá (see Figure 2). The exact boundaries of the river basin were identified using a map from the Brazilian National Water Agency (ANA 2006).

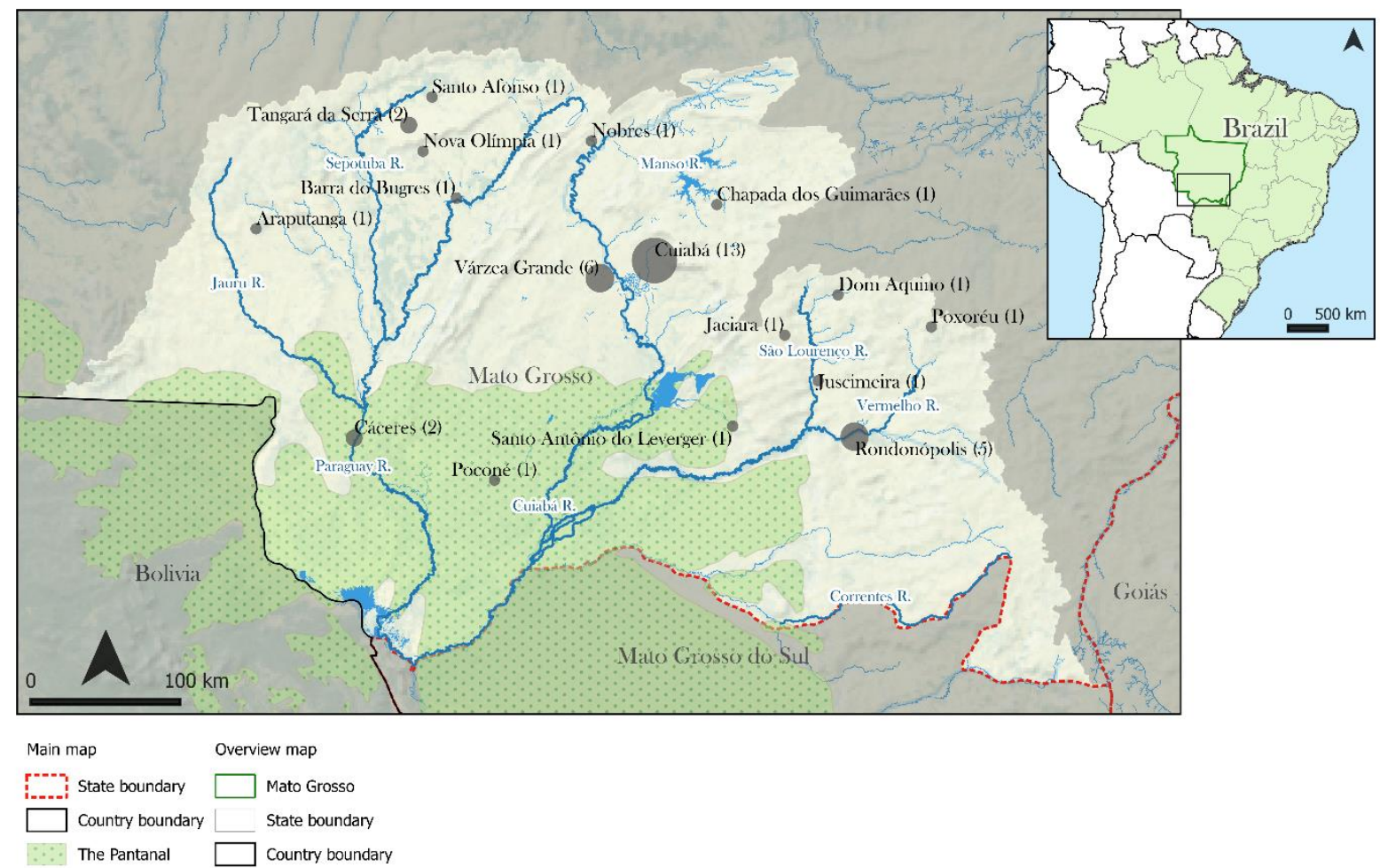

Figure 2: Sampled census tracts in the Upper Paraguay River Basin, Mato Grosso; numbers indicate the number of sampled census tracts per municipality (source of city locations, rivers, waterbodies: (C) OpenStreetMap contributors) USE COLOUR ONLINE ONLY

Sampling occurred during two stages. First, 40 census tracts (i.e. small geographical units created by the Brazilian Institute for Geography and Statistics, IBGE, to facilitate household sampling) within the Upper Paraguay River Basin were randomly sampled with probability proportionate to size sampling as outlined in Turner (2003), then 30 households within each census tract, using sample frames and address lists from IBGE (IBGE 2011a, 2011b, 2011c) were sampled (see supplementary material S1 for 
the list of sampled census tracts). Generally at least two attempts were made to interview a member of a specific household that was randomly sampled from address lists. In case of repeated nonresponse, replacement rules were in place which defined how to randomly select an alternative household from the respective address list. Within-household selection of respondents was determined by the household, limited to adults, as is often done in survey research (Gaziano 2005). The overall response rate (completed interviews at targeted households divided by number of households approached) was $43.77 \%$, the size of the working sample for subsequent analysis was $\mathrm{N}=1028$ for the full structural equation model. In case of missing data, cases were deleted listwise, which affected no more than $3.94 \%$ of overall observations at any point. This is below the $5 \%$ threshold that Garson (2015) recommends for using listwise deletion.

To assess the representativeness of our sample, socio-demographic characteristics of respondents were compared with data from the 2010 IBGE census (see Table 3/Appendix A and supplementary material S2). Our sample approximates representativeness as only the difference in proportions for the variable 'occupational status' is statistically significant, likely in part due to increased unemployment levels in 2016 as a result of economic recession in Brazil.

\subsection{Questionnaire design}

The questionnaire used in our survey consisted of five sections that were analysed for the present study (socio-demographics; fundamental values; governance-related values; assigned values; water policy preferences regarding the Paraguay-Paraná Waterway). To measure a respondent's fundamental values, we used Schwartz' universal value framework, and specifically, the Portrait Value Questionnaire (PVQ) with 21 items introduced by Schwartz (2001). It has been translated into Portuguese for the European Social Science Survey and was developed precisely to allow easy application to any type of respondent irrespective of age, cultural, or educational background. Furthermore, it has been tested in numerous studies around the globe, including in Brazil (Tamayo \& Porto 2009). Another advantage of using the PVQ instead of alternative measurement instruments for fundamental values typically used e.g. in environmental psychology studies is its broad applicability beyond purely environmental topics. While the measurement instruments developed e.g. by Steg, Perlaviciute et al. (2014) or Stern et al. (1998) were explicitly developed to measure values that might influence a person's attitudes towards the environment and pro-environmental behaviour, these instruments do not have any obvious connection with governance and governance-related values. This is why we selected Schwartz' PVQ (Schwartz 2001), which measures very broad personal values that would be equally relevant to both governance-related values as well as specific environmental issues and values. The exact list of the 21 survey items of the PVQ that we used in our study can be found in Schwartz (2001: 284-286; see also supplementary material S3).

With regards to governance-related values and assigned values, no existing measurement instruments were readily available. For the case of governance-related values we were not aware of any instrument that would have been widely tested and developed, whereas assigned values are too context-specific to be elicited with a standardised measurement instrument (Ives \& Kendal 2014; Seymour et al. 2010). Thus we relied on the list of values identified by Schulz et al. (2017b) (and Schulz \& loris 2017) in an exploratory study with local stakeholders to design our survey items, assuming that these would be appropriate in the local context (see Tables 1 and 2). For both governance-related values and assigned values, respondents first picked their 'most important item', and were then asked to rate the relative importance of remaining items on a scale from 1 to 5 , with 5 indicating equal importance, and 1 indicating no importance. This combination of a qualitative value description with 
a relative rating exercise is in line with the definition of assigned values presented earlier, which combines qualitative and quantitative aspects (Brown 1984; Ives \& Kendal 2014; Mclntyre et al. 2008) (see supplementary material S3 where the exact question stems for assigned values and governancerelated values are listed).

The items were classified into three factors (i.e. latent variables) each, using exploratory factor analysis (EFA), although one factor within governance-related values was later excluded from the analysis (see supplementary material S4). Respondents were also asked whether they would support or oppose the waterway if a hypothetical referendum was held about its construction. This question was preceded by a brief description of the controversy that aimed to be as neutral and balanced as possible, citing advantages and disadvantages that have been mentioned in the media, academic literature, and in stakeholder interviews (Schulz et al. 2017b) (see supplementary material S5 for the full description of the advantages and disadvantages of the Paraguay-Paraná Waterway that survey respondents were given).

Table 1: Assigned values (i.e. water values): List of items

\begin{tabular}{cl}
\hline $\begin{array}{c}\text { Cultural water } \\
\text { values }\end{array}$ & $\begin{array}{l}\text { Traditional lifestyles, for example artisanal fishing or use of clay for ceramics, } \\
\text { depend on rivers. } \\
\text { Mato Grosso's culture has a strong relationship with the rivers and } \\
\text { waterbodies, for example during traditional festivities. }\end{array}$ \\
$\begin{array}{c}\text { Economic water } \\
\text { values }\end{array}$ & $\begin{array}{l}\text { The state's economy depends on water abundance, especially for agriculture } \\
\text { and cattle ranching. } \\
\text { The rivers produce almost all electric energy that is used in Mato Grosso. }\end{array}$ \\
$\begin{array}{c}\text { Ecological } \\
\text { water values }\end{array}$ & $\begin{array}{l}\text { The rivers sustain the nature of the Pantanal wetland. } \\
\text { The rivers and waterbodies are important for the survival of wildlife, for } \\
\text { example jaguars, birds, caimans etc. }\end{array}$ \\
\hline
\end{tabular}

Table 2: Governance-related values: List of items

\begin{tabular}{cl}
\hline Democratic governance-related values & Follow the opinion of the majority of the \\
(democratic legitimacy and social justice) & $\begin{array}{l}\text { population. } \\
\text { Care about the poor and minorities. }\end{array}$ \\
$\begin{array}{c}\text { Economic governance-related values } \\
\text { (economic efficiency and rule of law/order) }\end{array}$ & $\begin{array}{l}\text { Not to waste public money. } \\
\text { Everyone follows the law. }\end{array}$ \\
\hline
\end{tabular}

\section{Results and discussion}

\subsection{Support and opposition to the construction of the Paraguay-Paraná Waterway}

Overall, $64.4 \%$ of respondents were opposed to the waterway and $33.6 \%$ were in favour (while $0.3 \%$ refused to answer and $1.7 \%$ didn't know), which is in itself an interesting result with clear policy relevance. To ascertain that this result was not driven by a potential implicit bias among interviewers or the description of the project, we also asked respondents, beforehand, whether they already knew about the project (64.8\% didn't, 35.2\% did). Among those respondents who stated to know about the project, $60.1 \%$ opposed it and $39.9 \%$ favoured it, which is close to the overall ratio of approval. Assuming that those respondents who knew about the project had already formed an opinion, this suggests that no obvious bias was induced through interviewers or the information provided. 


\subsection{A structural equation model of value landscapes and their impact on water policy preferences}

The 'final' empirical output of the present paper is a structural equation model of our respondents' value landscapes and their impact on respondents' water policy preferences, in this case in favour or against the construction of the Paraguay-Paraná Waterway in the Pantanal wetland of Mato Grosso, Brazil (visualised in Figure 3; full model parameters in Table 4/Appendix B). Due to limitations of space, we cannot outline the entire model development process here, which consisted of exploratory factor analyses (EFAs) for governance-related values and assigned values, confirmatory factor analyses (CFAs) for fundamental, governance-related, and assigned values (to validate the measurement model of our structural equation model), as well as conceptual considerations informing the final structure or path model of our structural equation model. Most details of EFAs and CFAs are instead presented in the supplementary material (sections S5 and S6).

The structural equation model was estimated with the lavaan package within $R$ (v. 0.5-23.1097) (Rosseel 2017). Having ordinal data, we used polychoric correlations for this analysis, which assumes that an underlying continuous variable is measured in a number of discrete categories (Garson 2015); a plausible assumption for people's values. Furthermore, we applied diagonally weighted least squares (DWLS) as a model estimation method, which is appropriate for categorical and ordinal data with sample sizes of around 1000 (Bandalos 2014). To evaluate model fit, we relied on a combination of absolute and incremental fit indexes (RMSEA, SRMR, CFI, TLI, and model $\chi^{2}$ significance) as is widely recommended in the SEM literature (Garson 2015; Hu \& Bentler 1999; Kline 2011). All indexes indicated good fit (i.e. RMSEA $<0.06$; SRMR<0.08; CFI/TLI $>0.95$ ), except model $\chi^{2}$, which is sample-size sensitive, and according to Garson (2015) may reject most models with a sample size above 200. All factor loadings are 0.45 or higher, indicating that our measurement model is acceptable (Stevens 2009).

From a conceptual point of view, the model was based on the two main hypotheses developed in section 3. That is, it was designed to apply the general framework of the Value Landscapes Approach (see Figure 1, section 2) to the case of public preferences regarding the Paraguay-Paraná Waterway, taking into account previous empirical research findings of the wider literature as well as of Schulz et al. (2017b). Here we discuss our findings regarding each hypothesis and their respective components. Based on ample previous evidence (Evans et al. 2013; Kilbourne et al. 2005; Schultz et al. 2005; Steg \& de Groot 2012), we assumed that self-transcendence and self-enhancement would be the main divergent relevant dimensions at the level of fundamental values, informing people's views on environmental issues. We then related these two main dimensions with the more concrete constructs of governance-related values and assigned values, which indeed produced mostly statistically significant links within each value landscape (see Figure 3). Given that Schulz et al. (2017b) had identified two separate value landscapes among their interviewees, we designed our model here accordingly, with no interlinkages between value landscape 1 (consisting of self-transcendence values, democratic governance-related values, cultural and ecological water values) and value landscape 2 (self-enhancement values, economic governance-related values, economic water values). 

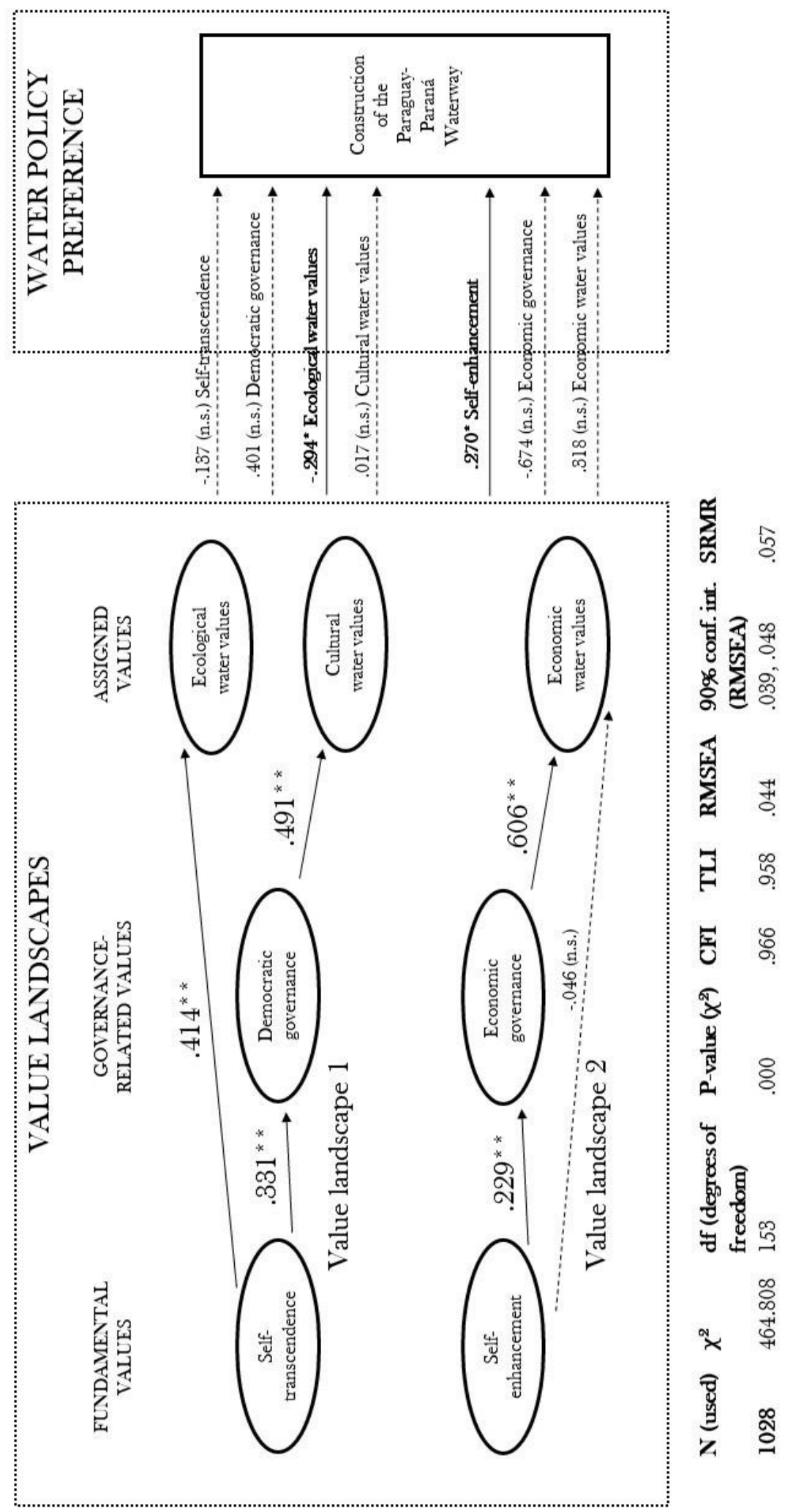

Figure 3: A structural equation model; dashed paths indicate non-statistically significant relations; * indicates significance at .05 level, ** indicates significance at .01 level. 


\subsection{Value landscapes relationships (Hypothesis 1)}

Findings with respect to Hypothesis 1 are split up into a number of components below, which all correspond to individual arrows in our structural equation model (see Figure 3 ).

Finding 1: Self-transcendence values relate positively with democratic governance-related values.

We expected that self-transcendence would have a positive association with democratic governancerelated values, given that the survey items measuring this type of values (see Table 2) both emphasise caring about other people and their views, which in turn relates well with the values of benevolence and universalism in the Schwartz survey (Schwartz 1992, 1994, 2001). We did find such a positive link that is statistically significant. This suggests that self-transcendence values are reflected in people's preferences for governance-related values such as social justice and democratic legitimacy.

Finding 2: Self-enhancement values relate positively with economic governance-related values.

We expected the self-enhancement dimension to relate positively with economic governance-related values, due to the emphasis of the related survey items (see Table 2) on efficiency and legality, which could plausibly be associated with the fundamental value of achievement in the self-enhancement dimension. We did find such a positive link that is statistically significant. This suggests that selfenhancement values are reflected in people's preferences for governance-related values such as economic efficiency and rule of law/order.

Finding 3: Self-transcendence values relate positively with ecological water values.

We expected that self-transcendence would relate positively with ecological water values, again in line with previous literature on environmental values more generally (Schultz et al. 2005; Steg \& de Groot 2012), as well as specific literature on the link between fundamental values and assigned values, as summarised in section 3 (Hicks et al. 2015; Van Riper \& Kyle 2014). This assumption is indeed confirmed by our data and model with statistically significant links.

Finding 4: Democratic governance-related values relate positively with cultural water values.

The status of cultural water values was less clear, but for the concrete case study context, we hypothesised that democratic governance-related values would relate positively with cultural values, given that in the Upper Paraguay River Basin, the conservation of water-related traditions, festivities, and culture rests upon marginalised and poor riparian communities (Schulz et al. 2017b), which in turn are the focus of the survey item for 'social justice', i.e. democratic governance-related values. We did not relate it with either fundamental value dimension in our model, given that we would expect cultural water values to be most closely related with Schwartz' $(1992,1994)$ conservation dimension (i.e. traditional values), which is not part of our model here. This relationship is found, too. We would be cautious to generalise this finding beyond the context of Mato Grosso, however, given that the link between culture, traditions and marginalisation (which could be addressed by better social justice and democratic legitimacy) is especially strong in this particular geographical area but might be less so in other contexts.

Finding 5: Self-enhancement values relate positively with economic water values.

We expected self-enhancement to relate positively with economic water values. This would be in line with previous findings of e.g. Kilbourne et al. (2005) who found that material values relate positively with self-enhancement (and one could conceive of economic water values produced by agriculture and hydroelectric power as material values). While this relationship does not appear as statistically significant in the full structural equation model presented in Figure 3, we found that this is entirely 
due to mediation effects, i.e. a situation where an independent variable has an effect on a dependent variable through a third (mediating) variable (Baron \& Kenny 1986; Zhao et al. 2010). It appears that in our model, the effect of the independent variable self-enhancement on the dependent variable economic water values is affected by the mediating variable economic governance-related values. Evidence for that is that if we delete the mediating variable economic governance-related values from the model, the relationship between self-enhancement and economic water values becomes statistically significant ( $p$-value of 0.021 ), with a coefficient of 0.119 . This is in line with our assumption that fundamental values may have an impact on both governance-related values and assigned values.

Finding 6: Economic governance-related values relate positively with economic water values.

The link between economic governance-related values and economic water values would be in line with the findings of Schulz et al. (2017b), where stakeholders typically expressed a preference for both efficiency and legality, as well as economic water values. This relationship was found and thus confirms the qualitative research of Schulz et al. (2017b). This link is especially significant given that it relates the level of governance-related values and of assigned values (as Finding 4), suggesting that these do indeed combine in value landscapes, as proposed in the Value Landscapes Approach.

\subsection{Impact of people's value landscapes on their water policy preferences (Hypothesis 2)}

Finding 1: Self-transcendence and ecological water values of value landscape 1 relate negatively with support for the Paraguay-Paraná Waterway (as an example of a water policy preference).

In the preceding qualitative study (Schulz et al. 2017b), stakeholders tended to oppose the construction of the Paraguay-Paraná Waterway when they also emphasised the importance of ecological and cultural water values, as well as governance-related values such as social justice and equity (i.e. democratic governance-related values), which are all related in value landscape 1 here. One could thus plausibly expect a negative link between these values and support for the waterway, not least also in line with environmental psychology literature on linkages between self-transcendence and pro-environmental attitudes and behaviour (Dietz 2016; Schultz et al. 2005; Steg \& de Groot 2012) and a study of Bjornlund et al. (2013) who found that pro-environmental fundamental values go along with support for pro-environmental water policies. However, only one value (ecological water values) was found to display a statistically significant relationship with the expected direction in the full model. In this case, mediation effects are only in part responsible for this (i.e. further unknown variables not accounted for in our model may also be relevant) - if one deletes ecological water values from the full model, the negative link between self-transcendence and the water policy preference becomes statistically significant ( $p$-value of 0.037 ; coefficient of -0.240 ). No mediation effect was found for democratic governance-related values, despite its strong links to self-transcendence and cultural water values in value landscape 1 , which suggests that this value by itself is unrelated to opposition to the waterway. The same applies to cultural water values.

Finding 2: Self-enhancement (of value landscape 2) and economic water values relate positively with support for the Paraguay-Paraná Waterway.

Stakeholders in Schulz et al. (2017b) tended to support the waterway when they also emphasised economic water values and governance-related values such as efficiency and order (i.e. economic governance-related values), which are all related in value landscape 2 here. Thus it seemed plausible that these values would relate positively with support for the project, not least considering the environmental psychology literature on the negative links between self-enhancement values and pro- 
environmental attitudes and behaviour (Dietz 2016; Schultz et al. 2005; Steg \& de Groot 2012), as well as the findings of Bjornlund et al. (2013) who reported that 'utilitarian values' (with a similar focus on economic aspects) went along with support for water policies aimed at enhancing economic activities in their survey. Again, only one value (self-enhancement) was found to display a statistically significant relationship with the expected direction. Moderator effects, where a third variable impacts on the relationship between an independent and a dependent variable (Baron \& Kenny 1986), are in part responsible (i.e. further unknown variables not accounted for in our model may also be relevant). When deleting the moderating variable of cultural water values (which in line with Preacher \& Hayes 2008 was linked to economic water values via residual covariances, see Table 4/Appendix B), the positive link between economic water values and the water policy preference becomes statistically significant ( $p$-value of 0.028 ), with a coefficient of 0.329 .

It seems plausible that, contrary to our initial expectations, economic governance-related values relate negatively to support for the waterway (coefficient of -0.674 with a p-value of 0.093 ). In practice, that would mean that concern for economic efficiency and legality of governance might combine with opposition to the project, possibly due to a concern with corruption and waste of public funds. The $p-$ value of that link falls below the more lenient 0.1 threshold for statistical significance that is occasionally applied, even if not typically recommended (El-Masri \& Tawadrous 2013). While our analysis should thus not be interpreted as conclusive empirical evidence on this specific link, it would resonate with academic literature on the waste of public funds in the context of large infrastructure projects in Mato Grosso (Crabb 2016) and Brazil more generally (Joly 2017; Signor et al. 2016), especially under the centre-left governments of Presidents Luiz Inácio 'Lula' da Silva and Dilma Rousseff (Armijo \& Rhodes 2017). This issue was particularly salient during fieldwork in 2016, i.e. when Brazilian news were dominated by the revelations about large-scale corruption following the investigations within 'Operation Car Wash' (Melo 2016; Winter 2017) that eventually resulted in the impeachment of President Dilma Rousseff (Santos \& Guarnieri 2016).

\section{Implications, general discussion, and conclusions}

Implementing a Value Landscapes Approach in empirical research more generally may (i) help to understand people's preferences and behaviour in water governance, including their water policy preferences and (ii) may serve to assess the political legitimacy of water governance in a given place and time by comparing values held by members of the general public with those values expressed in actual water governance. Specific relations between values and water policy preferences were amply discussed in the preceding sections. Here, instead, we aim to situate our research findings in the wider literature. Our finding that preferences for or against the construction of a waterway across Mato Grosso's Pantanal wetland can be linked to people's values is in line with the general environmental psychology literature, which has a long history of establishing linkages between fundamental values, other psychological constructs, and people's preferences (Dietz 2016; Fulton et al. 1996; Homer \& Kahle 1988; Steg \& de Groot 2012; Steg 2016). Our study confirms what Manfredo et al. (2017a) have called the 'embedded nature of values' in society; values are not just psychometric constructs that can be measured via survey instruments, but are realised in many different ways in society, including in material objects, such as plans to build a waterway in our case.

Understanding conflicts and controversies as conflicts of values is highly significant with practical implications, given that value conflicts tend to activate people's emotions, escalate quickly, and often persist over significant timespans (Illes et al. 2014; Korper et al. 1986; Kouzakova et al. 2012). Addressing such conflicts requires particular conflict resolution techniques that go beyond a mere 
comparison of all stakeholders' interests. Harinck and Druckman (2017) report that using the help of mediators who affirm the positive qualities of other parties in joint negotiations might be a promising conflict resolution strategy for value conflicts, because this reduces threats to the identity of each conflicting party that arise whenever people's values are concerned. Our findings suggest that the conflict around this water project is indeed a conflict of values as proposed by Schulz et al. (2017b). This would explain its long conflict history and the emotional disputes around it, which at an earlier stage attracted attention by local and international NGOs (da Silva et al. 2004; Figueiredo et al. 2012; Leão et al. 2013).

Beyond our individual case study, our findings indicate that other classical environmental conservation vs. economic development conflicts may be rooted in people's values, too. While such a statement is in line with findings by environmental psychologists on linkages between values and environmental attitudes or preferences (Dietz 2016; Schultz et al. 2005; Steg \& de Groot 2012) and the finding of Drews and van den Bergh (2016) that self-enhancement (and conservation) values might be correlated with a preference for economic growth, we are not aware of previous research that has sought to interpret these environment vs. development conflicts generally as conflicts of fundamental values. The environment-development interface is more typically discussed from an economics or international development perspective (e.g. Aguilar-Støen et al. 2016; Halkos \& Managi 2017; Paavola 2002; Xepapadeas \& Stefan 2014) or in the context of localised conflicts between environmental conservation and economic activities (e.g. Arvor et al. 2018; Hoyman \& McCall 2013; Martín-López et al. 2011; Rajwade 2015). Where values are mentioned in this context, they usually concern assigned values (e.g. Bergseng \& Vatn 2009; Karjalainen \& Järvikoski 2010).

Interpreting environment vs. development conflicts as conflicts of fundamental values would explain why these are so widespread not just in Mato Grosso and Brazil (see e.g. Arvor et al. 2018; Nascimento \& Griffith 2012; Schulz et al. 2015; Zhouri 2010), but globally, and why they are so frequently perceived as intractable and difficult to resolve. Moreover, it could explain why attempts to overcome the divide between environmental conservation and economic development ring hollow to many, e.g. when researchers express their discomfort with monetary valuation of the environment (e.g. Harvey 1996; Kallis et al. 2013; Spangenberg \& Settele 2010; Spash \& Vatn 2006) or when they express their doubts about the adequacy of the 'green growth' concept (e.g. Bina 2013; Death 2014; Schulz \& Bailey 2014; Springett 2013). It also suggests that individual cases of environment vs. development conflicts could be addressed with conflict resolution techniques which have proven effective specifically for situations of value conflict (see e.g. Harinck \& Druckman 2017; Illes et al. 2014; Karjalainen \& Järvikoski 2010; Kouzakova et al. 2012), even if the broader dynamics of conflict between environment and development dimensions are unlikely to disappear.

Our structural equation model confirmed the existence of links between fundamental values and assigned values that had been identified with different methodological approaches previously (Hicks et al. 2015; Van Riper \& Kyle 2014), especially the link between self-transcendence and assigning ecological values to water. Yet, by including governance-related values as well, our study adds a new facet of the value concept to the analysis that is not typically included in environmental psychology research, despite its importance for water governance (Glenk \& Fischer 2010; Grotenbreg \& Altamirano 2017; Schulz 2018) and public administration (Beck Jørgensen \& Bozeman 2007; de Graaf et al. 2016; Rutgers 2015; Tsanga Tabi \& Verdon 2015). Further research on value landscapes, and the role of governance-related values therein, should thus be conducted to evaluate their importance for understanding water governance preferences, based on our initial findings here.

Finally, the empirical evidence presented in this study strengthens the case of political ecologists and critical scholars who claim that water governance in Brazil (and possibly in many other countries) is 
driven by elites and ignores preferences of the public and weaker stakeholder groups (e.g. loris 2009; Lemos \& de Oliveira 2004; Martins 2015; Schmitt 2016; Siegmund-Schultze et al. 2015). The values and preferences expressed by the general public in our survey do not match the values and preferences expressed by Mato Grosso's water governance, i.e. the plans to build a waterway in the Pantanal wetland, as evidenced by the fact that almost two thirds of respondents opposed it. The economic water values that would be realised through the waterway may thus not align with the predominantly environmental values of water that the majority of the population seems to prioritise. This points to problems with its political legitimacy, if understood as majority support of the population (Bekkers \& Edwards 2007). It may also indicate that the pessimism of many water professionals in Mato Grosso about lacking environmental awareness among the general population (Schulz \& loris 2017) may not necessarily be justified. Rather, environmental degradation would be the result of the disproportional political clout of a minority who prioritise economic water values. Not least, our study also serves to demonstrate that statistical analysis techniques have their place in answering questions of relevance to political ecologists, whose publications are dominated by qualitative and conceptual research approaches.

Conceivably, the research approach adopted here could serve for the analysis of other controversial projects, e.g. the construction of further waterways and large dams in the Brazilian Amazon (see e.g. Carvalho 2006; Fearnside 2015), as well as in many other countries around the globe which are currently experiencing a boom in hydropower development (Richter et al. 2010; Zarfl et al. 2015). And while the Value Landscapes Approach was developed in the context of water governance, it may also be of use for investigating any other aspect of environmental governance more generally that may be characterised by conflicting underlying value landscapes.

\section{References}

Aguilar-Støen, M., Hansen, A., McNeill, D., \& Stølen, K.-A. (2016): Introduction to the Special Issue: Frontiers of Research on Development and the Environment, in: Forum for Development Studies, vol. 43(1): 1-4.

Ajzen, I. (1985): From Intentions to Actions: A Theory of Planned Behavior, in: Kuhl, J., \& Beckmann, J. (eds.): Action Control: From Cognition to Behavior, Berlin \& Heidelberg, Germany: Springer-Verlag, 11-39.

Ajzen, I. (1991): The theory of planned behavior, in: Organizational Behavior and Human Decision Processes, vol. 50(2): 179-211.

Akhmouch, A. \& Correia, F.N. (2016): The 12 OECD principles on water governance - When science meets policy, in: Utilities Policy, vol. 43: 14-20.

ANA = Agência Nacional de Águas (2006): Região Hidrográfica do Paraguai [map], ANA. Available online:

http://metadados.ana.gov.br/geonetwork/srv/en/resources.get?id=114\&fname=REGIAO HIDROGR AFICA DO PARAGUAI.pdf\&access=private (last accessed 20/3/2017).

ANTAQ = Agência Nacional de Transportes Aquaviários (2013): Relatório Técnico: Bacia do Paraguai, in: ANTAQ, UFSC = Universidade Federal de São Carlos, \& LabTrans = Laboratório de Transportes e Logística (eds.): Plano Nacional de Integração Hidroviária: Desenvolvimento de Estudos e Análises das Hidrovias Brasileiras e suas Instalações Portuárias com Implantação de Base de Dados 
Georreferenciada e Sistema de Informações Geográficas, Brasília \& Florianópolis, Brazil: ANTAQ, UFSC \& LabTrans.

Antunes, P., Kallis, G., Videira, N., \& Santos, R. (2009): Participation and evaluation for sustainable river basin governance, in: Ecological Economics, vol. 68: 931-939.

Arévalo, D. (2015): Vice-governador discute hidrovia com investidores dos EUA, Governo do Estado de Mato Grosso, 12 February 2015. Available online:

http://www3.mt.gov.br/editorias/infraestrutura/vice-governador-discute-hidrovia-cominvestidores-dos-eua/135529 (last accessed 26/2/2018).

Arias-Arévalo, P., Martín-López, B., \& Gómez-Baggethun, E. (2017): Exploring intrinsic, instrumental, and relational values for sustainable management of social-ecological systems, in: Ecology and Society, vol. 22(4): 43.

Armijo, L.E. \& Rhodes, S.D. (2017): Explaining infrastructure underperformance in Brazil: cash, political institutions, corruption, and policy Gestalts, in: Policy Studies, vol. 38(3): 231-247.

Arvor, D., Daugeard, M., Tritsch, I., De Mello-Thery, N.A., Thery, H., \& Dubreuil, V. (2018): Combining socioeconomic development with environmental governance in the Brazilian Amazon: the Mato Grosso agricultural frontier at a tipping point, in: Environment, Development and Sustainability, vol. 20(1): 1-22.

Bandalos, D.L. (2014): Relative Performance of Categorical Diagonally Weighted Least Squares and Robust Maximum Likelihood Estimation, in: Structural Equation Modeling, vol. 21: 102-116.

Barber, M. \& Jackson, S. (2011): Aboriginal water values and resource development pressures in the Pilbara region of north-west Australia, in: Australian Aboriginal Studies, issue 2: 32-49.

Bark, R., MacDonald, D.H., Connor, J., Crossman, N., \& Jackson, S. (2011): Water Values, in: Prosser, I.P. (ed.): Water: Science and Solutions for Australia, Collingwood, Australia: CSIRO Publishing, 17-27.

Baron, R.M. \& Kenny, D.A. (1986): The Moderator-Mediator Variable Distinction in Social Psychological Research: Conceptual, Strategic, and Statistical Considerations, in: Journal of Personality and Social Psychology, vol. 51(6): 1173-1182.

Beck Jørgensen, T. \& Bozeman, B. (2007): Public Values: An Inventory, in: Administration \& Society, vol. 39(3): 354-381.

Bekkers, V. \& Edwards, A. (2007): Legitimacy and Democracy: A Conceptual Framework for Assessing Governance Practices, in: Bekkers, V., Dijkstra, G., Edwards, A., \& Fenger, M. (eds.): Governance and the Democratic Deficit: Assessing the Democratic Legitimacy of Governance Practices, Aldershot, UK \& Burlington, USA: Ashgate Publishing, 35-60.

Bengston, D.N. (1994): Changing forest values and ecosystem management, in: Society \& Natural Resources, vol. 7(6): 515-533.

Bergseng, E. \& Vatn, A. (2009): Why protection of biodiversity creates conflict - Some evidence from the Nordic countries, in: Journal of Forest Economics, vol. 15(3): 147-165.

Berry, K.A., Jackson, S., Saito, L., \& Forline, L. (2018): Reconceptualising Water Quality Governance to Incorporate Knowledge and Values: Case studies from Australian and Brazilian Indigenous Communities, in: Water Alternatives, vol. 11(1): 40-60. 
Bina, O. (2013): The green economy and sustainable development: an uneasy balance? in: Environment and Planning C: Government and Policy, vol. 31: 1023-1047.

Bjornlund, H. \& O'Callaghan, B. (2005): A Comparison of Implicit Values and Explicit Prices of Water, in: Pacific Rim Property Research Journal, vol. 11(3): 316-331.

Bjornlund, H., Parrack, C., \& de Loë, R.C. (2013): Segmenting the Urban and Rural Populations of Southern Alberta for Improved Understanding of Policy Preferences for Water Reallocation, in: Society \& Natural Resources, vol. 26(11): 1330-1350.

Braito, M.T., Böck, K., Flint, C., Muhar, A., Muhar, S., \& Penker, M. (2017): Human-nature relationships and linkages to environmental behaviour, in: Environmental Values, vol. 26: 365-389.

Brown, G. (2013): Relationships between spatial and non-spatial preferences and place-based values in national forests, in: Applied Geography, vol. 44: 1-11.

Brown, G. \& Reed, P. (2000): Validation of a Forest Values Typology for Use in National Forest Planning, in: Forest Science, vol. 46(2): 240-247.

Brown, T.C. (1984): The Concept of Value in Resource Allocation, in: Land Economics, vol. 60(3), 231246.

Calheiros, D.F., de Oliveira, M.D., \& Padovani, C.R. (2012): Hydro-ecological Processes and Anthropogenic Impacts on the Ecosystem Services of the Pantanal Wetland, in: loris, A.A.R. (ed.): Tropical Wetland Management: The South-American Pantanal and the International Experience, Farnham, UK: Ashgate Publishing, 29-57.

Carvalho, G.O. (2006): Environmental Resistance and the Politics of Energy Development in the Brazilian Amazon, in: The Journal of Environment \& Development, vol. 15(3): 245-268.

Chan, K.M.A., Satterfield, T., \& Goldstein, J. (2012): Rethinking ecosystem services to better address and navigate cultural values, in: Ecological Economics, vol. 74: 8-18.

Cooper, B. (2017): What drives compliance? An application of the theory of planned behaviour to urban water restrictions using structural equation modelling, in: Applied Economics, vol. 49(14): 1426-1439.

Corral-Verdugo, V., Carrus, G., Bonnes, M., Moser, G., \& Sinha, J.B.P. (2008): Environmental Beliefs and Endorsement of Sustainable Development Principles in Water Conservation: Toward a New Human Interdependence Paradigm Scale, in: Environment and Behavior, vol. 40(5): 703-725,

Crabb, L.A.H. (2016): Elites and carbon offsetting in Brazil: A critique of the 2014 FIFA World Cup in Mato Grosso, PhD thesis, Essex, UK: Essex Business School, University of Essex.

Cramer, L.A., Kennedy, J.J., Krannich, R.S., \& Quigley, T.M. (1993): Changing Forest Service Values and Their Implications for Land Management Decisions Affecting Resource-Dependent Communities, in: Rural Sociology, vol. 58(3): 475-491.

Crompton, T., Brewer, J., Chilton, P., \& Kasser, T. (2010): Common Cause: The Case for Working with our Cultural Values, Woking, UK: WWF-UK.

da Silva, H.P., Rocha, N.M., \& Ikeda-Castrillon, S.K. (2004): O impacto da proposta de implementação da Hidrovia Paraguai-Paraná, na visão de diversos setores da sociedade em Cáceres, MT, in: Anais do 
IV Simpósio sobre Recursos Naturais e Sócio-econômicos do Pantanal (SIMPAN), Corumbá, Brazil, 2326 November.

Daly, H.E. (1990): Toward some operational principles of sustainable development, in: Ecological Economics, vol. 2(1): 1-6.

de Graaf, G., Huberts, L., \& Smulders, R. (2016): Coping With Public Value Conflicts, in: Administration \& Society, vol. 48(9): 1101-1127.

Death, C. (2014): The Green Economy in South Africa: Global Discourses and Local Politics, in: Politikon, vol. 41(1): 1-22.

Dietz, T. (2016): Environmental value, in: Brosch, T. \& Sander, D. (eds.): Handbook of Value: Perspectives from Economics, Neuroscience, Philosophy, Psychology and Sociology, Oxford, UK: Oxford University Press, 329-349.

Dietz, T., Fitzgerald, A., \& Shwom, R. (2005): Environmental Values, in: Annual Review of Environment and Resources, vol. 30: 335-372.

Drews, S. \& van den Bergh, J.C.J.M. (2016): Public views on economic growth, the environment and prosperity: Results of a questionnaire survey, in: Global Environmental Change, vol. 39: 1-14.

Du Pisani, J.A. (2006): Sustainable development - historical roots of the concept, in: Environmental Sciences, vol. 3(2): 83-96.

El-Masri, M.M. \& Tawadrous, D. (2013): Essentials of Epidemiologic Measures and Data Interpretation, in: Korniewicz, D.M. (ed.): Infection Control for Advanced Practice Professionals, Lancaster, USA: DEStech Publications, Inc., 49-67.

Euzen, A. \& Morehouse, B. (2011): Water: What values? in: Policy and Society, vol. 30(4): 237-247.

Evans, L., Maio, G.R., Corner, A., Hodgetts, C.J., Ahmed, S., \& Hahn, U. (2013): Self-interest and proenvironmental behaviour, in: Nature Climate Change, vol. 3: 122-125.

Falk, A. \& Szech, N. (2013): Morals and Markets, in: Science, vol. 340(6133): 707-711.

Fearnside, P.M. (2001): Soybean cultivation as a threat to the environment in Brazil, in: Environmental Conservation, vol. 28(1): 23-38.

Fearnside, P.M. (2015): Amazon dams and waterways: Brazil's Tapajós Basin plans, in: Ambio, vol. 44(5): 426-439.

Figueiredo, D.M., Dores, E.F.G.C., Paz, A.R., \& Souza, C.F. (2012): Availability, Uses and Management of Water in the Brazilian Pantanal, in: loris, A.A.R. (ed.): Tropical Wetland Management: The SouthAmerican Pantanal and the International Experience, Farnham, UK: Ashgate Publishing, 59-98.

Floress, K., García de Jalón, S., Church, S.P., Babin, N., Ulrich-Schad, J.D., \& Prokopy, L.S. (2017): Toward a theory of farmer conservation attitudes: Dual interests and willingness to take action to protect water quality, in: Journal of Environmental Psychology, vol. 53: 73-80.

Fulton, D.C., Manfredo, M.J., \& Lipscomb, J. (1996): Wildlife Value Orientations: A Conceptual and Measurement Approach, in: Human Dimensions of Wildlife, vol. 1(2): 24-47.

Garson, G.D. (2015): Structural Equation Modeling, Asheboro, USA: Statistical Associates Publishers. 
Gaziano, C. (2005): Comparative Analysis of Within-Household Respondent Selection Techniques, in: Public Opinion Quarterly, vol. 69(1): 124-157.

Gibbs, L.M. (2010): "A beautiful soaking rain": environmental value and water beyond Eurocentrism, in: Environment and Planning D: Society and Space, vol. 28(2): 363-378.

Gioia, C.J. (1987): The Great Waterways project of South America, in: Project Appraisal, vol. 2(4): 243-250.

Glenk, K. \& Fischer, A. (2010): Insurance, prevention or just wait and see? Public preferences for water management strategies in the context of climate change, in: Ecological Economics, vol. 69(11): 2279-2291.

Gottgens, J.F., Perry, J.E., Fortney, R.H., Meyer, J.E., Benedict, M., \& Rood, B.E. (2001): The Paraguay-Paraná Hidrovía: Protecting the Pantanal with Lessons from the Past, in: BioScience, vol. 51(4): 301-308.

Grizzetti, B., Liquete, C., Antunes, P., Carvalho, L., Geamănă, N., Giucă, R., Leone, M., McConnell, S., Preda, E., Santos, R., Turkelboom, F., Vădineanu, A., \& Woods, H. (2016): Ecosystem services for water policy: Insights across Europe, in: Environmental Science \& Policy, vol. 66: 179-190.

Groenfeldt, D. (2013): Water ethics: A values approach to solving the water crisis, Abingdon, UK \& New York, USA: Routledge.

Grotenbreg, S. \& Altamirano, M. (2017): Government facilitation of external initiatives: how Dutch water authorities cope with value dilemmas, in: International Journal of Water Resources Development, Epub ahead of print: doi: 10.1080/07900627.2017.1374930.

Hackbart, V.C.S., de Lima, G.T.N.P., \& dos Santos, R.F. (2017): Theory and practice of water ecosystem services valuation: Where are we going? in: Ecosystem Services, vol. 23: 218-227.

Halkos, G. \& Managi, S. (2017): Recent advances in empirical analysis on growth and environment: introduction, in: Environment and Development Economics, vol. 22(6): 649-657.

Hamilton, S.K. (1999): Potential Effects of a Major Navigation Project (Paraguay-Paraná Hidrovía) on Inundation in the Pantanal Floodplains, in: Regulated Rivers: Research \& Management, vol. 15: 289299.

Harinck, F. \& Druckman, D. (2017): Do Negotiation Interventions Matter? Resolving Conflicting Interests and Values, in: Journal of Conflict Resolution, vol. 61(1): 29-55.

Harvey, D. (1996): Justice, Nature and the Geography of Difference, Cambridge, USA: Blackwell Publishers.

Henry, A.D. \& Dietz, T. (2012): Understanding Environmental Cognition, in: Organization \& Environment, vol. 25(3): 238-258.

Hermans, L.M., van Halsema, G.E., \& Mahoo, H.F. (2006): Building a mosaic of values to support local water resources management, in: Water Policy, vol. 8(5): 415-434.

Hicks, C.C., Cinner, J.E., Stoeckl, N., \& McClanahan, T.R. (2015): Linking ecosystem services and human-values theory, in: Conservation Biology, vol. 29(5): 1471-1480.

Homer, P.M. \& Kahle, L.R. (1988): A Structural Equation Test of the Value-Attitude-Behavior Hierarchy, in: Journal of Personality and Social Psychology, vol. 54(4): 638-646. 
Hoyman, M.M. \& McCall, J.R. (2013): Is there trouble in paradise? The perspectives of Galapagos community leaders on managing economic development and environmental conservation through ecotourism policies and the Special Law of 1998, in: Journal of Ecotourism, vol. 12(1): 33-48.

Hu, L. \& Bentler, P.M. (1999): Cutoff Criteria for Fit Indexes in Covariance Structure Analysis: Conventional Criteria Versus New Alternatives, in: Structural Equation Modeling, vol. 6(1): 1-55.

Hurlimann, A., Hemphill, E., McKay, J., \& Geursen, G. (2008): Establishing components of community satisfaction with recycled water use through a structural equation model, in: Journal of Environmental Management, vol. 88(4): 1221-1232.

IBGE = Instituto Brasileiro de Geografia e Estatística (2011a): Censo Demográfico 2010: Resultados da Sinopse por Setores Censitários (Mato Grosso) - 01/07/11 [dataset]. Available online:

ftp://ftp.ibge.gov.br/Censos/Censo Demografico 2010/Sinopse/Agregados por Setores Censitario s/Base informacoes setores2010 sinopse MT.zip (last accessed 20/3/2017).

IBGE (2011b): Base de informações do Censo Demográfico 2010: Resultados do Universo por setor censitário, Documentação do Arquivo, Rio de Janeiro: IBGE.

IBGE (2011c): Censo Demográfico 2010: Cadastro Nacional de Endereços para Fins Estatísticos (Mato Grosso) - 25/11/11 [dataset]. Available online:

ftp://ftp.ibge.gov.br/Censos/Censo Demografico 2010/Cadastro Nacional de Enderecos Fins Est atisticos/MT/ (last accessed 20/3/2017).

Illes, R., Ellemers, N., \& Harinck, F. (2014): Mediating Value Conflicts, in: Conflict Resolution Quarterly, vol. 31(3): 331-354.

Ioris, A.A.R. (2009): Water reforms in Brazil: opportunities and constraints, in: Journal of Environmental Planning and Management, vol. 52(6): 813-832.

Ioris, A.A.R. (2012): The Positioned Construction of Water Values: Pluralism, Positionality and Praxis, in: Environmental Values, vol. 21: 143-162.

Ioris, A.A.R. (2013): Rethinking Brazil's Pantanal Wetland: Beyond Narrow Development and Conservation Debates, in: The Journal of Environment \& Development, vol. 22(3): 239-260.

Ioris, A.A.R. (2016): Controversial Frontiers of Agricultural Development and Environmental Change, in: Ioris, A.A.R. (ed.): Agriculture, Environment and Development: International Perspectives on Water, Land and Politics, London, UK: Palgrave Macmillan, 221-250.

Iribarnegaray, M.A. \& Seghezzo, L. (2012): Governance, Sustainability and Decision Making in Water and Sanitation Management Systems, in: Sustainability, vol. 4: 2922-2945.

Ives, C.D. \& Fischer, J. (2017): The self-sabotage of conservation: reply to Manfredo et al., in: Conservation Biology, vol. 31(6): 1483-1485.

Ives, C.D. \& Kendal, D. (2014): The role of social values in the management of ecological systems, in: Journal of Environmental Management, vol. 144: 67-72.

Johnston, P., Everard, M., Santillo, D., \& Robèrt, K.-H. (2007): Reclaiming the Definition of Sustainability, in: Environmental Science and Pollution Research, vol. 14(1): 60-66.

Joly, M. (2017): Corruption: The shortcut to disaster, in: Sustainable Production and Consumption, vol. 10: 133-156. 
Junk, W.J., Nunes da Cunha, C., Wantzen, K.M., Petermann, P., Strüssman, C., Marques, M.I., \& Adis, J. (2006): Biodiversity and its conservation in the Pantanal of Mato Grosso, Brazil, in: Aquatic Sciences, vol. 68: 278-309.

Kaida, N. \& Kaida, K. (2016): Facilitating Pro-environmental Behavior: The Role of Pessimism and Anthropocentric Environmental Values, in: Social Indicators Research, vol. 126(3): 1243-1260.

Kallis, G., Gómez-Baggethun, E., \& Zografos, C. (2013): To value or not to value? That is not the question, in: Ecological Economics, vol. 94: 97-105.

Karjalainen, T.P. \& Järvikoski, T. (2010): Negotiating river ecosystems: Impact assessment and conflict mediation in the cases of hydro-power construction, in: Environmental Impact Assessment Review, vol. 30(5): 319-327.

Kilbourne, W., Grünhagen, M., \& Foley, J. (2005): A cross-cultural examination of the relationship between materialism and individual values, in: Journal of Economic Psychology, vol. 26(5): 624-641.

Kline, R.B. (2011): Principles and Practice of Structural Equation Modeling, $3^{\text {rd }}$ ed., New York, USA: The Guilford Press.

Kooiman, J. \& Jentoft, S. (2009): Meta-Governance: Values, Norms and Principles, and the Making of Hard Choices, in: Public Administration, vol. 87(4): 818-836.

Korper, S.H., Druckman, D., \& Broome, B.J. (1986): Value Differences and Conflict Resolution, in: The Journal of Social Psychology, vol. 126(3): 415-417.

Kouzakova, M., Ellemers, N., Harinck, F., \& Scheepers, D. (2012): The Implications of Value Conflict: How Disagreement on Values Affects Self-Involvement and Perceived Common Ground, in: Personality and Social Psychology Bulletin, vol. 38(6): 798-807.

Kuzdas, C., Wiek, A., Warner, B., Vignola, R., \& Morataya, R. (2014): Sustainability Appraisal of Water Governance Regimes: The Case of Guanacaste, Costa Rica, in: Environmental Management, vol. 54(2): 205-222.

Lathuillière, M.J., Johnson, M.S., Galford, G.L., \& Couto, E.G. (2014): Environmental footprints show China and Europe's evolving resource appropriation for soybean production in Mato Grosso, Brazil, in: Environmental Research Letters, vol. 9(7): 074001.

Leão, D.d.S., El Hage, P.P.F., \& Bampi, A.C. (2013): Sociedade Civil de Cáceres/MT no Monitoramento da Hidrovia Paraguai-Paraná (HPP) no Pantanal Mato-Grossense, in: Revista GeoPantanal, vol. 8(14): 46-66.

Lemos, M.C. \& de Oliveira, J.L.F. (2004): Can Water Reform Survive Politics? Institutional Change and River Basin Management in Ceará, Northeast Brazil, in: World Development, vol. 32(12): 2121-2137.

Lieberherr, E., Klinke, A., \& Finger, M. (2012): Towards Legitimate Water Governance? The partially privatized Berlin waterworks, in: Public Management Review, vol. 14(7): 923-946.

Lockwood, M. (1999): Humans Valuing Nature: Synthesising Insights from Philosophy, Psychology and Economics, in: Environmental Values, vol. 8: 381-401.

Lockwood, M., Davidson, J., Curtis, A., Stratford, E., \& Griffith, R. (2010): Governance principles for natural resource management, in: Society \& Natural Resources, vol. 23(10), 986-1001. 
Lukasiewicz, A., Bowmer, K., Syme, G.J., \& Davidson, P. (2013): Assessing Government Intentions for Australian Water Reform Using a Social Justice Framework, in: Society \& Natural Resources, vol. 26(11): 1314-1329.

Manfredo, M.J., Bruskotter, J.T., Teel, T.L., Fulton, D., Schwartz, S.H., Arlinghaus, R., Oishi, S., Uskul, A.K., Redford, K., Kitayama, S., \& Sullivan, L. (2017a): Why social values cannot be changed for the sake of conservation, in: Conservation Biology, vol. 31(4): 772-780.

Manfredo, M.J., Bruskotter, J.T., Teel, T.L., Fulton, D.C., Oishi, S., Uskul, A.K., Redford, K.H., Schwartz, S.H., Arlinghaus, R., Kitayama, S., \& Sullivan, L. (2017b): Revisiting the challenge of intentional value shift: reply to Ives and Fischer, in: Conservation Biology, vol. 31(6): 1486-1487.

Manning, R., Valliere, W., \& Minteer, B. (1999): Values, Ethics, and Attitudes Toward National Forest Management: An Empirical Study, in: Society \& Natural Resources, vol. 12(5): 421-436.

Martín-López, B., García-Llorente, M., Palomo, I., \& Montes, C. (2011): The conservation against development paradigm in protected areas: Valuation of ecosystem services in the Doñana socialecological system (southwestern Spain), in: Ecological Economics, vol. 70(8): 1481-1491.

Martin-Ortega, J., Ferrier, R.C., \& Gordon, I.J. (2015): Water ecosystem services: Moving forward, in: Martin-Ortega, J., Ferrier, R.C., Gordon, I.J., \& Khan, S. (eds.): Water ecosystem services: a global perspective, Cambridge, UK: Cambridge University Press, 170-173.

Martinez-Alier, J., Munda, G., \& O’Neill, J. (1998): Weak comparability of values as a foundation for ecological economics, in: Ecological Economics, vol. 26(3): 277-286.

Martins, R.C. (2015): Boundaries between Inequality and Difference in Water Governance, in: Ambiente \& Sociedade, vol. 18(1): 211-228.

McIntyre, N., Moore, J., \& Yuan, M. (2008): A Place-Based, Values-Centered Approach to Managing Recreation on Canadian Crown Lands, in: Society \& Natural Resources, vol. 21(8): 657-670.

Melo, M.A. (2016): Crisis and Integrity in Brazil, in: Journal of Democracy, vol. 27(2): 50-65.

Milman, A. \& Short, A. (2008): Incorporating resilience into sustainability indicators: An example for the urban water sector, in: Global Environmental Change, vol. 18(4): 758-767.

Moreno Pires, S., Teles, F., \& Ferreira da Cruz, N. (2017): Quality of local governance and sustainable development: a review of normative principles, paper presented at: $23^{\text {rd }}$ Annual International Sustainable Development Research Society (ISDRS) Conference, Universidad de los Andes, Bogotá, Colombia, 14-16 June.

Moss, T. \& Newig, J. (2010): Multilevel Water Governance and Problems of Scale: Setting the Stage for a Broader Debate, in: Environmental Management, vol. 46(1): 1-6.

Mostert, E. (2015): Who should do what in environmental management? Twelve principles for allocating responsibilities, in: Environmental Science \& Policy, vol. 45: 123-131.

Nascimento, A. \& Griffith, J.J. (2012): Environmental Philosophy in Brazil: Roots, Intellectual Culprits, and New Directions, in: Environmental Ethics, vol. 34: 379-397.

Norton, B.G. (2017): A Situational Understanding of Environmental Values and Evaluation, in: Ecological Economics, vol. 138: 242-248. 
Norton, B.G. \& Steinemann, A.C. (2001): Environmental Values and Adaptive Management, in: Environmental Values, vol. 10(4): 473-506.

Paavola, J. (2002): Environment and Development: Dissecting the Connections, in: Forum for Development Studies, vol. 29(1): 5-31.

Pascual, U., Balvanera, P., Díaz, S., Pataki, G., Roth, E., Stenseke, M., Watson, R.T., Başak Dessane, E., Islar, M., Kelemen, E., Maris, V., Quaas, M., Subramanian, S.M., Wittmer, H., Adlan, A., Ahn, S.E., AlHafedh, Y.S., Amankwah, E., Asah, S.T., Berry, P., Bilgin, A., Breslow, S.J., Bullock, C., Cáceres, D., Daly-Hassen, H., Figueroa, E., Golden, C.D., Gómez-Baggethun, E., González-Jiménez, D., Houdet, J., Keune, H., Kumar, R., Ma, K., May, P.H., Mead, A., O'Farrell, P., Pandit, R., Pengue, W., PichisMadruga, R., Popa, F., Preston, S., Pacheco-Balanza, D., Saarikoski, H., Strassburg, B.B., van den Belt, M., Verma, M., Wickson, F., \& Yagi, N. (2017): Valuing nature's contributions to people: the IPBES approach, in: Current Opinion in Environmental Sustainability, vol. 26: 7-16.

Patrick, M.J. (2014): The Cycles and Spirals of Justice in water-allocation decision making, in: Water International, vol. 39(1): 63-80.

Peine, E.K. (2013): Trading on Pork and Beans: Agribusiness and the Construction of the Brazil-ChinaSoy-Pork Commodity Complex, in: James Jr., H.S. (ed.): The Ethics and Economics of Agrifood Competition, The International Library of Environmental, Agricultural and Food Ethics vol. 20, Dordrecht, Netherlands: Springer Science+Business Media, 193-210.

Perreault, T. (2014): What kind of governance for what kind of equity? Towards a theorization of justice in water governance, in: Water International, vol. 39(2): 233-245.

Pires, M.A.F. \& da Silva, P.J. (2009): Hidrovia Paraná-Paraguai: um eixo de desenvolvimento, integração e sustentabilidade para a América do Sul, in: Engenharia, vol. 592: 132-136.

Poortinga, W., Steg, L., \& Vlek, C. (2004): Values, Environmental Concern, and Environmental Behavior: A Study Into Household Energy Use, in: Environment and Behavior, vol. 36(1): 70-93.

Pradhananga, A.K., Davenport, M.A., Fulton, D.C., Maruyama, G.M., \& Current, D. (2017): An Integrated Moral Obligation Model for Landowner Conservation Norms, in: Society \& Natural Resources, vol. 30(2): 212-227.

Preacher, K.J. \& Hayes, A.F. (2008): Asymptotic and resampling strategies for assessing and comparing indirect effects in multiple mediator models, in: Behavior Research Methods, vol. 40(3): 879-891.

Rahnama, H. \& Rajabpour, S. (2017): Identifying effective factors on consumers' choice behavior toward green products: the case of Tehran, the capital of Iran, in: Environmental Science and Pollution Research, vol. 24(1): 911-925.

Rajwade, A. (2015): The Indian Ocean Archipelagos: A Comparative Study of their Conservation vs. Development Spectrum, in: Local Government Quarterly, vol. 85(1): 66-79.

Raymond, C.M. \& Kenter, J.O. (2016): Transcendental values and the valuation and management of ecosystem services, in: Ecosystem Services, vol. 21(B): 241-257.

Richter, B.D., Postel, S., Revenga, C., Scudder, T., Lehner, B., Churchill, A., \& Chow, M. (2010): Lost in Development's Shadow: The Downstream Human Consequences of Dams, in: Water Alternatives, vol. 3(2): 14-42. 
Rokeach, M. (1973): The Nature of Human Values, New York, USA: The Free Press.

Rosseel, Y. (2017): The lavaan tutorial, Ghent, Belgium: Department of Data Analysis, Ghent University. Available online: http://lavaan.ugent.be/tutorial/tutorial.pdf (last accessed 16/2/2018).

Rutgers, M.R. (2015): As Good as It Gets? On the Meaning of Public Value in the Study of Policy and Management, in: The American Review of Public Administration, vol. 45(1): 29-45.

Sabatier, P.A. (1988): An advocacy coalition framework of policy change and the role of policyoriented learning therein, in: Policy Sciences, vol. 21(2-3): 129-168.

Sabatier, P.A. \& Weible, C.M. (2007): The Advocacy Coalition Framework: Innovations and Clarifications, in: Sabatier, P.A. (ed.): Theories of the Policy Process, $2^{\text {nd }}$ ed., Boulder, USA: Westview Press, 189-220.

Saliba, B.C., Bush, D.B., Martin, W.E., \& Brown, T.C. (1987): Do Water Market Prices Appropriately Measure Water Values? in: Natural Resources Journal, vol. 27(3): 617-651.

Salvaggio, M., Futrell, R., Batson, C.D., \& Brents, B.G. (2014): Water scarcity in the desert metropolis: how environmental values, knowledge and concern affect Las Vegas residents' support for water conservation policy, in: Journal of Environmental Planning and Management, vol. 57(4): 588-611.

Sanderson, M.R., Bergtold, J.S., Heier Stamm, J.L., Caldas, M.M., \& Ramsey, S.M. (2017): Bringing the "social" into sociohydrology: Conservation policy support in the Central Great Plains of Kansas, USA, in: Water Resources Research, vol. 53(8): 6725-6743.

Santos, F. \& Guarnieri, F. (2016): From Protest to Parliamentary Coup: An Overview of Brazil's Recent History, in: Journal of Latin American Cultural Studies, vol. 25(4): 485-494.

Schmitt, T. (2016): Immer Ärger mit der Materialität? - Politische Ökologie und das Dispositiv der Dürre im Nordosten Brasiliens, in: Geographica Helvetica, vol. 71(4): 229-244.

Schröter, M., van der Zanden, E.H., van Oudenhoven, A.P.E., Remme, R.P., Serna-Chavez, H.M., de Groot, R.S., \& Opdam, P. (2014): Ecosystem Services as a Contested Concept: A Synthesis of Critique and Counter-Arguments, in: Conservation Letters, vol. 7(6): 514-523.

Schultz, P.W., Gouveia, V.V., Cameron, L.D., Tankha, G., Schmuck, P., \& Franěk, M. (2005): Values and their Relationship to Environmental Concern and Conservation Behavior, in: Journal of CrossCultural Psychology, vol. 36(4): 457-475.

Schulz, C. (2018): Governance-related values as dimensions of good water governance, in: Wiley Interdisciplinary Reviews: Water, e1322, doi:10.1002/wat2.1322.

Schulz, C. \& Bailey, I. (2014): The green economy and post-growth regimes: opportunities and challenges for economic geography, in: Geografiska Annaler: Series B, Human Geography, vol. 96(3): 277-291.

Schulz, C. \& loris, A.A.R. (2017): The Paradox of Water Abundance in Mato Grosso, Brazil, in: Sustainability, vol. 9(10): 1796.

Schulz, C., loris, A.A.R., Martin-Ortega, J., \& Glenk, K. (2015): Prospects for Payments for Ecosystem Services in the Brazilian Pantanal: A Scenario Analysis, in: The Journal of Environment \& Development, vol. 24(1): 26-53. 
Schulz, C., Martin-Ortega, J., Glenk, K., \& Ioris, A.A.R. (2017a): The Value Base of Water Governance: A Multi-Disciplinary Perspective, in: Ecological Economics, vol. 131: 241-249.

Schulz, C., Martin-Ortega, J., loris, A.A.R., \& Glenk, K. (2017b): Applying a 'Value Landscapes Approach' to Conflicts in Water Governance: The Case of the Paraguay-Paraná Waterway, in: Ecological Economics, vol. 138: 47-55.

Schwartz, S.H. (1992): Universals in the Content and Structure of Values: Theoretical Advances and Empirical Tests in 20 Countries, in: Zanna, M.P. (ed.): Advances in Experimental Social Psychology, vol. 25, San Diego, USA: Academic Press, 1-65.

Schwartz, S.H. (1994): Are There Universal Aspects in the Structure and Contents of Human Values? in: Journal of Social Issues, vol. 50(4): 19-45.

Schwartz, S. (2001): A Proposal for Measuring Value Orientations across Nations, in: European Social Survey (ed.): European Social Survey Core Questionnaire Development, London, UK: City University London, 259-319.

Schwartz, S.H. \& Bilsky, W. (1987): Toward a Universal Psychological Structure of Human Values, in: Journal of Personality and Social Psychology, vol. 53(3): 550-562.

Schwartz, S.H. \& Boehnke, K. (2004): Evaluating the structure of human values with confirmatory factor analysis, in: Journal of Research in Personality, vol. 38(3): 230-255.

Schwartz, S.H., Cieciuch, J., Vecchione, M., Davidov, E., Fischer, R., Beierlein, C., Ramos, A., Verkasalo, M., Lönnqvist, J., Demirutku, K., Dirilen-Gümüş, Ö., \& Konty, M. (2012): Refining the Theory of Basic Individual Values, in: Journal of Personality and Social Psychology, vol. 103(4): 663688.

Seymour, E., Curtis, A., Pannell, D., Allan, C., \& Roberts, A. (2010): Understanding the role of assigned values in natural resource management, in: Australasian Journal of Environmental Management, vol. 17(3): 142-153.

Seymour, E., Curtis, A., Pannell, D.J., Roberts, A., \& Allan, C. (2011): Same river, different values and why it matters, in: Ecological Management \& Restoration, vol. 12(3): 207-213.

Sherrouse, B.C., Clement, J.M., \& Semmens, D.J. (2011): A GIS application for assessing, mapping, and quantifying the social values of ecosystem services, in: Applied Geography, vol. 31(2): 748-760.

Shin, Y.H., Moon, H., Jung, S.E., \& Severt, K. (2017): The effect of environmental values and attitudes on consumer willingness to pay more for organic menus: A value-attitude-behavior approach, in: Journal of Hospitality and Tourism Management, vol. 33: 113-121.

Sieber, R. (2006): Public Participation Geographic Information Systems: A Literature Review and Framework, in: Annals of the Association of American Geographers, vol. 96(3): 491-507.

Siegmund-Schultze, M., Rodorff, V., Köppel, J., \& do Carmo Sobral, M. (2015): Paternalism or participatory governance? Efforts and obstacles in implementing the Brazilian water policy in a large watershed, in: Land Use Policy, vol. 48: 120-130.

Signor, R., Love, P.E.D., \& Olatunji, O. (2016): Determining Overpricing in Brazilian Infrastructure Projects: A Forensic Approach, in: Journal of Construction Engineering and Management, vol. 142(9): 06016001. 
Small, N., Munday, M., \& Durance, I. (2017): The challenge of valuing ecosystem services that have no material benefits, in: Global Environmental Change, vol. 44: 57-67.

Spangenberg, J.H. \& Settele, J. (2010): Precisely incorrect? Monetising the value of ecosystem services, in: Ecological Complexity, vol. 7(3): 327-337.

Spash, C.L. \& Vatn, A. (2006): Transferring environmental value estimates: Issues and alternatives, in: Ecological Economics, vol. 60(2): 379-388.

Springett, D. (2013): Editorial: Critical Perspectives on Sustainable Development, in: Sustainable Development, vol. 21(2): 73-82.

Steg, L. (2016): Values, Norms, and Intrinsic Motivation to Act Proenvironmentally, in: Annual Review of Environment and Resources, vol. 41: 277-292.

Steg, L. \& de Groot, J.I.M. (2012): Environmental Values, in: Clayton, S.D. (ed.): The Oxford Handbook of Environmental and Conservation Psychology, New York, USA: Oxford University Press, 81-92.

Steg, L., Bolderdijk, J.W., Keizer, K., \& Perlaviciute, G. (2014): An Integrated Framework for Encouraging Pro-environmental Behaviour: The role of values, situational factors and goals, in: Journal of Environmental Psychology, vol. 38: 104-115.

Steg, L., Perlaviciute, G., van der Werff, E., \& Lurvink, J. (2014): The Significance of Hedonic Values for Environmentally Relevant Attitudes, Preferences, and Actions, in: Environment and Behavior, vol. 46(2): 163-192.

Stern, P.C., Dietz, T., Abel, T., Guagnano, G.A., \& Kalof, L. (1999): A Value-Belief-Norm Theory of Support for Social Movements: The Case of Environmentalism, in: Human Ecology Review, vol. 6(2): 81-97.

Stern, P.C., Dietz, T., \& Guagnano, G.A. (1998): A Brief Inventory of Values, in: Educational and Psychological Measurement, vol. 58(6): 984-1001.

Stern, P.C., Dietz, T., Kalof, L., \& Guagnano, G.A. (1995): Values, Beliefs, and Proenvironmental Action: Attitude Formation Toward Emergent Attitude Objects, in: Journal of Applied Social Psychology, vol. 25(18): 1611-1636.

Stevens, J.P. (2009): Applied multivariate statistics for the social sciences, $5^{\text {th }}$ ed., New York, USA \& Hove, UK: Routledge.

Tadaki, M., Sinner, J., \& Chan, K.M.A. (2017): Making sense of environmental values: a typology of concepts, in: Ecology and Society, vol. 22(1): 7.

Tamayo, A. \& Porto, J.B. (2009): Validação do Questionário de Perfis de Valores (QPV) no Brasil, in: Psicologia: Teoria e Pesquisa, vol. 25(3): 369-376.

Tang, J., Folmer, H., \& Xue, J. (2015): Technical and allocative efficiency of irrigation water use in the Guanzhong Plain, China, in: Food Policy, vol. 50: 43-52.

Taylor, P.D., Fahrig, L., Henein, K., \& Merriam, G. (1993): Connectivity is a vital element of landscape structure, in: Oikos, vol. 68(3): 571-573.

Toma, L., McVittie, A., Hubbard, C., \& Stott, A.W. (2011): A Structural Equation Model of the Factors Influencing British Consumers' Behaviour toward Animal Welfare, in: Journal of Food Products Marketing, vol. 17(2-3): 261-278. 
Treib, O., Bähr, H., \& Falkner, G. (2007): Modes of governance: towards a conceptual clarification, in: Journal of European Public Policy, vol. 14(1): 1-20.

Tsanga Tabi, M. \& Verdon, D. (2015): Les valeurs ont-elles une place dans le management des services publics ? Leçons d'une recherche-action, in: Revue Française de Gestion, vol. 250: 105-124.

Turner, A.G. (2003): Sampling Strategies, ESA/STAT/AC.93/2, New York, USA: Statistics Division, United Nations Secretariat.

UFPR/ITTI = Universidade Federal do Paraná/Instituto Tecnológico de Transporte e Infraestrutura (2016): Hidrovia do Rio Paraguai: EVTEA - Estudo de Viabilidade Técnica, Econômica e Ambiental, Informativo, Edição Única, Curitiba, Brazil: UFPR/ITTI.

van Leeuwen, C.J., Frijns, J., van Wezel, A., \& van de Wen, F.H.M. (2012): City Blueprints: 24 Indicators to Assess the Sustainability of the Urban Water Cycle, in: Water Resources Management, vol. 26: 2177-2197.

van Meerkerk, I., Edelenbos, J., \& Klijn, E.-H. (2015): Connective management and governance network performance: the mediating role of throughput legitimacy. Findings from survey research on complex water projects in the Netherlands, in: Environment and Planning C: Government and Policy, vol. 33: 746-764.

Van Riper, C.J. \& Kyle, G.T. (2014): Capturing multiple values of ecosystem services shaped by environmental worldviews: A spatial analysis, in: Journal of Environmental Management, vol. 145: 374-384.

van Schie, N., Duijn, M., \& Edelenbos, J. (2011): Co-valuation: Exploring methods for expert and stakeholder valuation, in: Journal of Environmental Assessment Policy and Management, vol. 13(4): 619-650.

Vaske, J.J. \& Donnelly, M.P. (1999): A Value-Attitude-Behavior Model Predicting Wildland Preservation Voting Intentions, in: Society \& Natural Resources, vol. 12(6): 523-537.

Winter, B. (2017): Brazil's never-ending corruption crisis: Why radical transparency is the only fix, in: Foreign Affairs, vol. 96(3): 87-94.

Xepapadeas, A. \& Stefan, J. (2014): Introduction: 20 years later, in: Environment and Development Economics, vol. 19(3): 271-284.

Yazdanpanah, M., Hayati, D., Hochrainer-Stigler, S., \& Zamani, G.H. (2014): Understanding farmers' intention and behavior regarding water conservation in the Middle-East and North Africa: A case study in Iran, in: Journal of Environmental Management, vol. 135: 63-72.

Young, H.P. (1994): Equity: In Theory and Practice, Princeton, USA: Princeton University Press.

Zarfl, C., Lumsdon, A.E., Berlekamp, J., Tydecks, L., \& Tockner, K. (2015): A global boom in hydropower dam construction, in: Aquatic Sciences, vol. 77(1): 161-170.

Zhao, X., Lynch Jr., J.G., \& Chen, Q. (2010): Reconsidering Baron and Kenny: Myths and Truths about Mediation Analysis, in: Journal of Consumer Research, vol. 37(2): 197-206.

Zhouri, A. (2010): "Adverse Forces" in the Brazilian Amazon: Developmentalism Versus Environmentalism and Indigenous Rights, in: The Journal of Environment \& Development, vol. 19(3): 252-273. 


\section{Appendix A}

Table 3: Pearson $\chi^{2}$ test of difference -Sample vs Upper Paraguay River Basin to evaluate sample representativeness; ** Difference between sample and UPRB is significant at the .01 level (2-sided).

\begin{tabular}{llll}
\hline Variable & $\boldsymbol{\chi}^{\mathbf{2}}$ & Degrees of freedom $(\mathrm{df})$ & p-value \\
\hline Location & 0.799 & 1 & 0.371 \\
Gender & 1.672 & 1 & 0.196 \\
Age & 6.408 & 12 & 0.894 \\
Household size & 1.839 & 5 & 0.871 \\
Formal education & 4.405 & 3 & 0.221 \\
Occupational status** & $\mathbf{7 . 1 3 3}$ & $\mathbf{1}$ & $\mathbf{0 . 0 0 8}$ \\
Monthly household income & 9.112 & 5 & 0.105 \\
\hline
\end{tabular}

\section{Appendix B}

Table 4: A structural equation model of value landscapes and their effect on water policy preferences.

\begin{tabular}{lllllllll}
\hline $\begin{array}{l}\mathbf{N} \\
\text { (used) }\end{array}$ & $\chi^{2}$ & $\begin{array}{l}\text { df (degrees of } \\
\text { freedom) }\end{array}$ & $\begin{array}{l}\text { P-value } \\
\left(\chi^{2}\right)\end{array}$ & CFI & TLI & RMSEA & $\begin{array}{l}\text { 90\% conf. int. } \\
\text { (RMSEA) }\end{array}$ & SRMR \\
\hline 1028 & 464.808 & 153 & .000 & .966 & .958 & .044 & $.039, .048$ & .057
\end{tabular}

LATENT VARIABLES

\begin{tabular}{|c|c|c|c|c|c|c|}
\hline $\begin{array}{l}\text { Latent variable } \\
\text { Self- }\end{array}$ & $\begin{array}{l}\text { Item/indicator } \\
\text { universalism } 1\end{array}$ & $\begin{array}{c}\text { Estimate } \\
1 \text { (fixed) }\end{array}$ & Std. err. & z-value & $P(>|z|)$ & $\begin{array}{c}\text { Std. est. } \\
.597\end{array}$ \\
\hline \multirow[t]{4}{*}{ transcendence } & universalism 2 & .964 & .056 & 17.305 & .000 & .575 \\
\hline & universalism 3 & 1.224 & .062 & 19.735 & .000 & .731 \\
\hline & benevolence 1 & 1.220 & .061 & 19.928 & .000 & .728 \\
\hline & benevolence 2 & 1.213 & .060 & 20.198 & .000 & .724 \\
\hline Self- & achievement 1 & 1 (fixed) & & & & .559 \\
\hline \multirow[t]{3}{*}{ enhancement } & achievement 2 & 1.137 & .065 & 17.475 & .000 & .636 \\
\hline & hedonism 1 & 1.205 & .072 & 16.831 & .000 & .674 \\
\hline & hedonism 2 & 1.031 & .064 & 16.140 & .000 & .576 \\
\hline \multirow[t]{2}{*}{$\begin{array}{l}\text { Democratic } \\
\text { governance }\end{array}$} & $\begin{array}{l}\text { democratic } \\
\text { legitimacy }\end{array}$ & 1 (fixed) & & & & .636 \\
\hline & social justice & 1.176 & .107 & 11.043 & .000 & .748 \\
\hline \multirow[t]{2}{*}{$\begin{array}{l}\text { Economic } \\
\text { governance }\end{array}$} & $\begin{array}{l}\text { economic } \\
\text { efficiency }\end{array}$ & 1 (fixed) & & & & .572 \\
\hline & rule of law/order & .832 & .107 & 7.800 & .000 & .476 \\
\hline \multirow[t]{2}{*}{$\begin{array}{l}\text { Cultural water } \\
\text { values }\end{array}$} & $\begin{array}{l}\text { traditional } \\
\text { lifestyles }\end{array}$ & 1 (fixed) & & & & .652 \\
\hline & $\begin{array}{l}\text { traditional } \\
\text { festivities }\end{array}$ & 1.026 & .086 & 11.908 & .000 & .670 \\
\hline \multirow{2}{*}{$\begin{array}{l}\text { Economic } \\
\text { water values }\end{array}$} & agriculture & 1 (fixed) & & & & .655 \\
\hline & $\begin{array}{l}\text { hydroelectric } \\
\text { power }\end{array}$ & .871 & .107 & 8.148 & .000 & .570 \\
\hline \multirow{2}{*}{$\begin{array}{l}\text { Ecological } \\
\text { water values }\end{array}$} & Pantanal's nature & 1 (fixed) & & & & .800 \\
\hline & wildlife & .885 & .098 & 9.070 & .000 & .708 \\
\hline
\end{tabular}




\begin{tabular}{|c|c|c|c|c|c|c|}
\hline $\begin{array}{l}\text { Dependent } \\
\text { variable }\end{array}$ & $\begin{array}{l}\text { Independent } \\
\text { variable }\end{array}$ & Estimate & Std. err. & z-value & $P(>|z|)$ & Std. est. \\
\hline $\begin{array}{l}\text { Democratic } \\
\text { governance }\end{array}$ & $\begin{array}{l}\text { Self- } \\
\text { transcendence }\end{array}$ & .353 & .053 & 6.603 & .000 & .331 \\
\hline $\begin{array}{l}\text { Economic } \\
\text { governance }\end{array}$ & $\begin{array}{l}\text { Self- } \\
\text { enhancement }\end{array}$ & .234 & .076 & 3.089 & .002 & .229 \\
\hline $\begin{array}{l}\text { Ecological } \\
\text { water values }\end{array}$ & $\begin{array}{l}\text { Self- } \\
\text { transcendence }\end{array}$ & .555 & .078 & 7.123 & .000 & .414 \\
\hline \multirow[t]{2}{*}{$\begin{array}{l}\text { Economic } \\
\text { water values }\end{array}$} & $\begin{array}{l}\text { Self- } \\
\text { enhancement }\end{array}$ & -.053 & .080 & -0.664 & .506 & -.046 \\
\hline & $\begin{array}{l}\text { Economic } \\
\text { governance }\end{array}$ & .694 & .103 & 6.711 & .000 & .606 \\
\hline $\begin{array}{l}\text { Cultural water } \\
\text { values }\end{array}$ & $\begin{array}{l}\text { Democratic } \\
\text { governance }\end{array}$ & .504 & .072 & 6.933 & .000 & .491 \\
\hline $\begin{array}{l}\text { Paraguay- } \\
\text { Paraná }\end{array}$ & $\begin{array}{l}\text { Self- } \\
\text { transcendence }\end{array}$ & -.230 & .237 & -.968 & .333 & -.137 \\
\hline $\begin{array}{l}\text { Waterway } \\
\text { policy }\end{array}$ & $\begin{array}{l}\text { Self- } \\
\text { enhancement }\end{array}$ & .483 & .211 & 2.290 & .022 & .270 \\
\hline \multirow[t]{5}{*}{ preference } & $\begin{array}{l}\text { Democratic } \\
\text { governance }\end{array}$ & .631 & .560 & 1.127 & .260 & .401 \\
\hline & $\begin{array}{l}\text { Economic } \\
\text { governance }\end{array}$ & -1.178 & .701 & -1.679 & .093 & -.674 \\
\hline & $\begin{array}{l}\text { Cultural water } \\
\text { values }\end{array}$ & .026 & .248 & .105 & .916 & .017 \\
\hline & $\begin{array}{l}\text { Economic water } \\
\text { values }\end{array}$ & .485 & .262 & 1.849 & .064 & .318 \\
\hline & $\begin{array}{l}\text { Ecological water } \\
\text { values }\end{array}$ & -.367 & .157 & -2.343 & .019 & -.294 \\
\hline \multicolumn{7}{|l|}{ COVARIANCE } \\
\hline $\begin{array}{l}\text { Latent variable } \\
1\end{array}$ & Latent variable 2 & Estimate & Std. err. & z-value & $P(>|z|)$ & Std. est. \\
\hline $\begin{array}{l}\text { Self- } \\
\text { transcendence }\end{array}$ & $\begin{array}{l}\text { Self- } \\
\text { enhancement }\end{array}$ & .200 & .015 & 13.079 & .000 & .598 \\
\hline \multicolumn{7}{|c|}{ RESIDUAL COVARIANCES } \\
\hline $\begin{array}{l}\text { Latent variable } \\
1\end{array}$ & Latent variable 2 & Estimate & Std. err. & z-value & $P(>|z|)$ & Std. est. \\
\hline $\begin{array}{l}\text { Democratic } \\
\text { governance }\end{array}$ & $\begin{array}{l}\text { Economic } \\
\text { governance }\end{array}$ & .278 & .032 & 8.696 & .000 & .834 \\
\hline \multirow[t]{2}{*}{$\begin{array}{l}\text { Cultural water } \\
\text { values }\end{array}$} & $\begin{array}{l}\text { Economic water } \\
\text { values }\end{array}$ & .161 & .028 & 5.809 & .000 & .539 \\
\hline & $\begin{array}{l}\text { Ecological water } \\
\text { values }\end{array}$ & .277 & .032 & 8.586 & .000 & .669 \\
\hline $\begin{array}{l}\text { Economic } \\
\text { water values }\end{array}$ & $\begin{array}{l}\text { Ecological water } \\
\text { values }\end{array}$ & .150 & .031 & 4.772 & .000 & .391 \\
\hline
\end{tabular}


Supplementary material for manuscript:

Value landscapes and their impact on public water policy preferences

Supplementary material S1: List of sampled census tracts

Table 5: Sampled census tracts in the Upper Paraguay River Basin

\begin{tabular}{|c|c|c|c|c|}
\hline Census tract no. & Municipality & Neighbourhood & $\begin{array}{l}\text { No. of } \\
\text { interviews }\end{array}$ & $\begin{array}{l}\text { Percent } \\
\text { (total) }\end{array}$ \\
\hline 510125805000006 & Araputanga & Centro/Santo Antônio & 30 & 2.8 \\
\hline 510170405000015 & Barra do Bugres & União & 31 & 2.9 \\
\hline 510250405000032 & Cáceres & Santos Dumont & 30 & 2.8 \\
\hline 510250405000103 & Cáceres & Monte Verde & 29 & 2.7 \\
\hline 510300710000006 & Chapada dos Guimarães & Various rural areas & 21 & 2.0 \\
\hline 510340305410011 & Cuiabá & Porto & 31 & 2.9 \\
\hline 510340305410071 & Cuiabá & Alvorada & 29 & 2.7 \\
\hline 510340305410137 & Cuiabá & Santa Rosa & 21 & 2.0 \\
\hline 510340305420012 & Cuiabá & Baú & 18 & 1.7 \\
\hline 510340305420074 & Cuiabá & Poção & 22 & 2.1 \\
\hline 510340310400010 & Cuiabá & Morada da Serra & 28 & 2.6 \\
\hline 510340310400067 & Cuiabá & Morada da Serra & 29 & 2.7 \\
\hline 510340310420002 & Cuiabá & Jardim das Américas & 28 & 2.6 \\
\hline 510340310420064 & Cuiabá & Jardim Renascer & 28 & 2.6 \\
\hline 510340310420128 & Cuiabá & Alphaville & 0 & 0 \\
\hline 510340310430054 & Cuiabá & Tijucal & 29 & 2.7 \\
\hline 510340310430107 & Cuiabá & Jardim Industriário & 29 & 2.7 \\
\hline 510340310430162 & Cuiabá & Tijucal & 29 & 2.7 \\
\hline 510360105000004 & Dom Aquino & Centro & 30 & 2.8 \\
\hline 510480705000015 & Jaciara & Santo Antônio & 30 & 2.8 \\
\hline 510520005000015 & Juscimeira & Cajus & 29 & 2.7 \\
\hline 510590305000006 & Nobres & São José & 29 & 2.7 \\
\hline 510623205000015 & Nova Olímpia & Jardim Ouro Verde & 25 & 2.3 \\
\hline 510650505000018 & Poconé & Areião/Jurumirim & 30 & 2.8 \\
\hline 510700805000013 & Poxoréu & Centro & 30 & 2.8 \\
\hline 510726305000012 & Santo Afonso & Various rural areas & 25 & 2.3 \\
\hline 510760205000055 & Rondonópolis & Jardim Tropical & 30 & 2.8 \\
\hline 510760205000126 & Rondonópolis & Vila Olinda & 29 & 2.7 \\
\hline 510760205000240 & Rondonópolis & La Salle-AG 32 & 20 & 1.9 \\
\hline 510760205000368 & Rondonópolis & Recanto Maria Flávia & 12 & 1.1 \\
\hline 510760230000078 & Rondonópolis & Jardim Sumaré & 30 & 2.8 \\
\hline 510780010000003 & Sto. Antônio do Leverger & Various rural areas & 30 & 2.8 \\
\hline 510795805000045 & Tangará da Serra & Vila Goiás/Jard. Acapulco & 30 & 2.8 \\
\hline 510795805000123 & Tangará da Serra & Jardim Paraíso & 25 & 2.3 \\
\hline 510840205000039 & Várzea Grande & Mapim & 27 & 2.5 \\
\hline 510840205000096 & Várzea Grande & Costa Verde & 25 & 2.3 \\
\hline 510840205000154 & Várzea Grande & Nova Várzea Grande & 28 & 2.6 \\
\hline 510840205000217 & Várzea Grande & Santa Isabel & 30 & 2.8 \\
\hline 510840220000006 & Várzea Grande & Construmat & 31 & 2.9 \\
\hline 510840220000062 & Várzea Grande & Construmat & 30 & 2.8 \\
\hline
\end{tabular}




\section{Supplementary material S2: Representativeness of sample}

Table 2 compares characteristics of the sampled respondents with those of the general population in the Upper Paraguay River Basin (based on data from IBGE, see footnotes for the exact sources).

Table 6: Representativeness of sample

\begin{tabular}{|c|c|c|c|}
\hline & & Sample & $\begin{array}{l}\text { Upper Paraguay } \\
\text { River Basin (UPRB) }\end{array}$ \\
\hline \multirow{2}{*}{ Location $^{1}$} & Urban & $92.9 \%$ & $89.3 \%$ \\
\hline & Rural & $7.1 \%$ & $10.7 \%$ \\
\hline \multirow{2}{*}{ Gender $^{4}$} & Male & $40.6 \%$ & $49.7 \%$ \\
\hline & Female & $59.4 \%$ & $50.3 \%$ \\
\hline \multirow{14}{*}{$\mathrm{Age}^{4}$} & $18-19$ & $3.9 \%$ & $5.2 \%$ \\
\hline & $20-24$ & $8.6 \%$ & $13.7 \%$ \\
\hline & $25-29$ & $8.3 \%$ & $13.4 \%$ \\
\hline & $30-34$ & $11.5 \%$ & $12.6 \%$ \\
\hline & $35-39$ & $9.4 \%$ & $11.1 \%$ \\
\hline & $40-44$ & $9.7 \%$ & $10.0 \%$ \\
\hline & $45-49$ & $9.9 \%$ & $8.7 \%$ \\
\hline & $50-54$ & $8.6 \%$ & $7.3 \%$ \\
\hline & $55-59$ & $9.7 \%$ & $5.6 \%$ \\
\hline & $60-64$ & $6.6 \%$ & $4.3 \%$ \\
\hline & $65-69$ & $6.7 \%$ & $3.1 \%$ \\
\hline & $70-74$ & $4.0 \%$ & $2.2 \%$ \\
\hline & 75 or more & $2.9 \%$ & $2.8 \%$ \\
\hline & Refused & $0.1 \%$ & - \\
\hline \multirow{6}{*}{$\begin{array}{l}\text { Household } \\
\text { size }^{2}\end{array}$} & 1 resident & $7.6 \%$ & $12.7 \%$ \\
\hline & 2 residents & $23.0 \%$ & $21.7 \%$ \\
\hline & 3 residents & $25.1 \%$ & $24.2 \%$ \\
\hline & 4 residents & $21.0 \%$ & $22.1 \%$ \\
\hline & 5 residents & $12.7 \%$ & $11.3 \%$ \\
\hline & 6 or more residents & $10.6 \%$ & $7.9 \%$ \\
\hline \multirow{3}{*}{$\begin{array}{l}\text { Formal } \\
\text { education }\end{array}$} & $\begin{array}{l}\text { No formal schooling / incomplete primary } \\
\text { school }\end{array}$ & $28.6 \%$ & $42.2 \%$ \\
\hline & $\begin{array}{l}\text { Primary school complete / incomplete high } \\
\text { school }\end{array}$ & $17.6 \%$ & $17.0 \%$ \\
\hline & $\begin{array}{l}\text { High school complete / incomplete higher } \\
\text { education }\end{array}$ & $38.0 \%$ & $29.5 \%$ \\
\hline
\end{tabular}

\footnotetext{
${ }^{1}$ Source: Table No. 1552, Census of 2010, IBGE, Rio de Janeiro (accessed through http://www2.sidra.ibge.gov.br ). Numbers for the UPRB were compiled using data at the district level for adults (18 years or older); see below for the exact list of districts.

${ }^{2}$ Source: Table No. 3219, Census of 2010, IBGE, Rio de Janeiro (accessed through http://www2.sidra.ibge.gov.br ). Numbers for the UPRB were compiled using data at the district level; see below for the exact list of districts.

${ }^{3}$ Source: Table No. 3540, Census of 2010, IBGE, Rio de Janeiro (accessed through http://www2.sidra.ibge.gov.br ). Numbers for the UPRB were compiled using data at the level of municipalities for adults (18 years or older); see below for the exact list of municipalities.
} 
Complete higher education

Occupational status $^{4}$

Monthly

household income $^{5}$
Economically active

Not economically active

Up to 1 minimum salary

1-2 minimum salaries

2-5 minimum salaries

5-10 minimum salaries

10-20 minimum salaries

More than 20 minimum salaries

Refused

Don't know

Note that the following municipalities were considered to be part of the Upper Paraguay River Basin:

Acorizal - MT; Alto Paraguai - MT; Araputanga - MT; Arenápolis - MT; Barão de Melgaço - MT; Barra do Bugres - MT; Cáceres - MT; Chapada dos Guimarães - MT; Cuiabá - MT; Curvelândia - MT; Denise - MT; Dom Aquino - MT; Figueirópolis D'Oeste - MT; Glória D'Oeste - MT; Guiratinga - MT; Indiavaí - MT; Itiquira - MT; Jaciara - MT; Jangada - MT; Jauru - MT; Juscimeira - MT; Lambari D'Oeste - MT; Mirassol d'Oeste - MT; Nobres - MT; Nortelândia - MT; Nossa Senhora do Livramento - MT; Nova Brasilândia - MT; Nova Olímpia - MT; Pedra Preta - MT; Poconé - MT; Porto Esperidião - MT; Porto Estrela - MT; Poxoréo - MT; São José dos Quatro Marcos - MT; Reserva do Cabaçal - MT; Rio Branco - MT; Santo Afonso - MT; São José do Povo - MT; São Pedro da Cipa - MT; Rondonópolis - MT; Rosário Oeste - MT; Salto do Céu - MT; Santo Antônio do Leverger - MT; Tangará da Serra - MT; Várzea Grande - MT; Nova Marilândia - MT.

Note that the following districts were considered to be part of the Upper Paraguay River Basin:

Acorizal - Acorizal - MT; Baús - Acorizal - MT; Aldeia - Acorizal - MT; Alto Paraguai - Alto Paraguai MT; Capão Verde - Alto Paraguai - MT; Lavouras - Alto Paraguai - MT; Araputanga - Araputanga - MT; Arenápolis - Arenápolis - MT; Barão de Melgaço - Barão de Melgaço - MT; Joselândia - Barão de Melgaço - MT; Barra do Bugres - Barra do Bugres - MT; Assari - Barra do Bugres - MT; Tapirapuã Barra do Bugres - MT; Cáceres - Cáceres - MT; Bezerro Branco - Cáceres - MT; Caramujo - Cáceres MT; Horizonte do Oeste - Cáceres - MT; Nova Cáceres - Cáceres - MT; Chapada dos Guimarães Chapada dos Guimarães - MT; Água Fria - Chapada dos Guimarães - MT; Rio da Casca - Chapada dos Guimarães - MT; Cuiabá - Cuiabá - MT; Coxipó da Ponte - Cuiabá - MT; Coxipó do Ouro - Cuiabá - MT; Guia - Cuiabá - MT; Curvelândia - Curvelândia - MT; Denise - Denise - MT; Dom Aquino - Dom Aquino - MT; Entre Rios - Dom Aquino - MT; Figueirópolis D'Oeste - Figueirópolis D'Oeste - MT; Glória D'Oeste - Glória D'Oeste - MT; Monte Castelo D'Oeste - Glória D'Oeste - MT; Vale Rico - Guiratinga MT; Indiavaí - Indiavaí - MT; Itiquira - Itiquira - MT; Jaciara - Jaciara - MT; Celma - Jaciara - MT; Jangada - Jangada - MT; Jauru - Jauru - MT; Lucialva - Jauru - MT; Juscimeira - Juscimeira - MT; Irenópolis - Juscimeira - MT; Santa Elvira - Juscimeira - MT; São Lourenço de Fátima - Juscimeira - MT;

\footnotetext{
${ }^{4}$ Source: Table No. 616, Census of 2010, IBGE, Rio de Janeiro (accessed through http://www2.sidra.ibge.gov.br ). Numbers for the UPRB were compiled using data at the level of municipalities for adults (18 years or older); see below for the exact list of municipalities.

${ }^{5}$ Source: Table No. 3562, Census of 2010, IBGE, Rio de Janeiro (accessed through http://www2.sidra.ibge.gov.br ). Numbers for the UPRB were compiled using data at the level of municipalities; see below for the exact list of municipalities. Note that in 2010 , a minimum salary was $R \$ 510$, whereas in 2016, it was R\$ 880.
} 
Lambari D'Oeste - Lambari D'Oeste - MT; Mirassol d'Oeste - Mirassol d'Oeste - MT; Sonho Azul Mirassol d'Oeste - MT; Nobres - Nobres - MT; Bom Jardim - Nobres - MT; Coqueiral - Nobres - MT; Nortelândia - Nortelândia - MT; Nossa Senhora do Livramento - Nossa Senhora do Livramento - MT; Pirizal - Nossa Senhora do Livramento - MT; Ribeirão dos Cocais - Nossa Senhora do Livramento - MT; Seco - Nossa Senhora do Livramento - MT; Nova Brasilândia - Nova Brasilândia - MT; Riolândia - Nova Brasilândia - MT; Nova Olímpia - Nova Olímpia - MT; Pedra Preta - Pedra Preta - MT; São José do Planalto - Pedra Preta - MT; Poconé - Poconé - MT; Cangas - Poconé - MT; Fazenda de Cima - Poconé - MT; Porto Esperidião - Porto Esperidião - MT; Porto Estrela - Porto Estrela - MT; Poxoréo - Poxoréo - MT; Alto Coité - Poxoréo - MT; Jarudore - Poxoréo - MT; Paraíso do Leste - Poxoréo - MT; São José dos Quatro Marcos - São José dos Quatro Marcos - MT; Santa Fé - São José dos Quatro Marcos - MT; Reserva do Cabaçal - Reserva do Cabaçal - MT; Rio Branco - Rio Branco - MT; Santo Afonso - Santo Afonso - MT; São José do Povo - São José do Povo - MT; Nova Catanduva - São José do Povo - MT; São Pedro da Cipa - São Pedro da Cipa - MT; Rondonópolis - Rondonópolis - MT; Anhumas Rondonópolis - MT; Nova Galiléia - Rondonópolis - MT; Boa Vista - Rondonópolis - MT; Vila Operária - Rondonópolis - MT; Rosário Oeste - Rosário Oeste - MT; Arruda - Rosário Oeste - MT; Bauxi - Rosário Oeste - MT; Marzagão - Rosário Oeste - MT; Salto do Céu - Salto do Céu - MT; Cristinópolis - Salto do Céu - MT; Vila Progresso - Salto do Céu - MT; Santo Antônio do Leverger - Santo Antônio do Leverger - MT; Engenho Velho - Santo Antônio do Leverger - MT; Mimoso - Santo Antônio do Leverger - MT; Caité - Santo Antônio do Leverger - MT; Varginha - Santo Antônio do Leverger - MT; Tangará da Serra - Tangará da Serra - MT; Progresso - Tangará da Serra - MT; São Joaquim - Tangará da Serra - MT; São Jorge - Tangará da Serra - MT; Várzea Grande - Várzea Grande - MT; Bom Sucesso - Várzea Grande MT; Passagem da Conceição - Várzea Grande - MT; Porto Velho - Várzea Grande - MT; Capão Grande - Várzea Grande - MT; Nova Marilândia - Nova Marilândia - MT.

Supplementary material S3: Question stems for assigned, governance-related, and fundamental values

Assigned values were elicited with the following 2-tiered question stem:

"Now I would like to talk about the rivers and waterbodies of Mato Grosso. I will mention 6 reasons why the rivers and waterbodies here are important, and I would like you to tell me which one is the most important one for you, in your personal opinion:

1) Traditional lifestyles, for example artisanal fishing or use of clay for ceramics, depend on rivers.

2) The state's economy depends on water abundance, especially for agriculture and cattle ranching.

3) The rivers sustain the nature of the Pantanal wetland.

4) Mato Grosso's culture has a strong relationship with the rivers and waterbodies, for example during traditional festivities.

5) The rivers produce almost all electric energy that is used in Mato Grosso.

6) The rivers and waterbodies are important for the survival of wildlife, for example jaguars, birds, caimans etc.

Now, that you mentioned [answer chosen above] as the most important value: please compare with the other values, what is the level of importance?"

[All 6 options are read again, except the one already selected above as most important, with the following answer options:] 
"Equally important (5); almost as important (4); a bit less important (3); much less important (2); not important (1)"

Governance-related values were elicited with the same 2-tiered system, making use of this question stem:

"Now I would like to know your opinions about some principles that could guide the authorities when they take decisions about water. Please tell me which of the following principles should be the most important for the authorities, in your opinion?

1) Think about the impact for future generations.

2) Not to waste public money.

3) Follow the opinion of the majority of the population.

4) Consult studies and experts.

5) Care about the poor and minorities.

6) Everyone follows the law.

Now, that you mentioned [governance-related value $\mathrm{X}$ ] as the most important principle: please compare with the other principles, what is the level of importance?"

[All 6 options are read again, except the one already selected above as most important, with the following answer options:]

"Equally important (5); almost as important (4); a bit less important (3); much less important (2); not important (1)"

Fundamental values were elicited with the Schwartz Portrait Value Questionnaire (PVQ), published in Schwartz (2001: 284-286), which is freely available online from the following source:

(https://www.europeansocialsurvey.org/docs/methodology/core ess questionnaire/ESS core ques tionnaire human values.pdf)

This part of the questionnaire was introduced as follows:

"The following questions are not going to be about water, but they will help to understand why people have certain opinions. I will describe people with different characteristics and will ask you to tell me how much each of these people is or is not similar to you."

So for example, to measure the fundamental value of 'benevolence', the following description was read to the respondents:

"A person to whom it's very important to help the people around them. They want to care for other people."

As another example, the following statement corresponded to the fundamental value of 'security':

"A person for whom it is important to live in secure surroundings. They avoid anything that might endanger their safety."

Respondents could then answer on a scale from 1 to 6 with the following options:

"Exactly like me (1); Very much like me (2); Like me (3); A little like me (4); Not like me (5); Not like me at all (6)" 


\section{Supplementary material S4: Exploratory factor analyses (EFAs) of governance-related values and assigned values}

Since we developed our own measurement instrument for assigned values and governance-related values, we used exploratory factor analysis (EFA) to establish how many latent variables our survey items captured and whether they represented distinct factors. We did this for assigned values and governance-related values separately, while no EFA was performed for fundamental values whose structure has been extensively tested in previous research (Schwartz et al. 2012). ${ }^{6}$ For assigned values, we had strong theoretical expectations, namely that we were measuring three distinct types of assigned values (cultural, ecological, and economic water values), but employed EFA in any case as our items had not been tested for the existence of latent variables previously. For governance-related values, we did not have specific theoretical expectations due to the lack of previous research, and our approach was fully exploratory (Schulz 2018). For the EFA, we used IBM SPSS (v.22), first with the six assigned value items, then with the six governance-related value items, which were formulated based on the previous research by Schulz et al. (2017); see also Tables 1 and 2 of the main manuscript. ${ }^{7}$ As a factor extraction method, we selected "principal axis factoring" (also known as 'principal factors'), which according to Brown (2006) and Fabrigar et al. (1999) is less prone to improper solutions and does not require distributional assumptions regarding the data. Another advantage of principal axis factoring is that it is more sensitive in the extraction of weaker factors and everything else being equal, almost always outperforms maximum likelihood factor analysis (de Winter \& Dodou 2012).

To determine the number of factors, we employed the "scree test", which involves plotting the initial eigenvalues of the factors against the number of factors (Brown 2006; Costello \& Osborne 2005). It has been suggested as an alternative to the popular, but somewhat arbitrary Kaiser-Guttman rule, which merely defines that additional factors with eigenvalues below 1.0 should be disregarded, thus often producing inaccurate results (Bandalos \& Boehm-Kaufman 2009). The plot is then inspected to identify the last substantial decline in the magnitude of eigenvalues to determine a cut-off point for the number of factors to be extracted. As a factor rotation method, we employed "promax" with Kaiser Normalisation, i.e. an oblique rotation method that allows latent variable to intercorrelate. This is opposed to orthogonal rotation methods such as "varimax", which would constrain factors to be fully uncorrelated, which we deemed inappropriate for our case, as we expected e.g. some correlation between cultural and ecological water values (Costello \& Osborne 2005). Factor rotation represents a mathematical transformation of the data which increases their interpretability as it selects those solutions among the infinite number of factor solutions in which factor loadings are closer to 1 and more distant from 0, respectively (Brown 2006).

For the EFA of assigned values, we found the last substantial decline in the magnitude of eigenvalues at around 0.8 , thus producing three latent variables or factors. Table 3 shows the rotated pattern

\footnotetext{
${ }^{6}$ An EFA with all indicators/items at once produces two factors: the first consisting of all assigned value items, and the second consisting of all governance-related items; this merely shows that all assigned value items indeed measure 'water values', and all governance-related value items indeed measure 'good governance'. For our study, more detail is judged more useful, despite the criticism of van der Eijk \& Rose (2015) and C. van der Eijk (personal communication, March 23, 2017) who warn about the risk of "over-dimensionalisation" from a data point of view.

${ }^{7}$ Two items measuring a third governance-related value which we called "scientific governance" (see below) were later dropped from the final structural equation model, so they are not mentioned in the main manuscript. These were items capturing sustainability and evidence-based policy-making. These were judged too ambiguous in the present research context, given that sustainability was universally claimed by all interviewees in the earlier study by Schulz et al. (2017), limiting its usefulness to distinguish between various value landscapes.
} 
matrix, i.e. the unique relationships between factors and items ('factor loadings'), with factors serving as predictors of the items (or 'indicators'). While there is no consensus in the literature what represents appropriate cut-off points for factor loadings (Peterson 2000), the results indicate quite unambiguously the existence of three separate types of water values, measured by two items each. Factor 1 in the table can be interpreted as 'ecological water values', factor 2 as 'cultural water values' and factor 3 as 'economic water values' as each one of them has relatively high loadings on two items and consistently low loadings on the remaining four items. While the results are not necessarily surprising, they confirm that our measurement of assigned values was indeed appropriate. The weakest loading is found with the item mentioning economic water values, agriculture, and cattle ranching on the factor 'economic water values'. From a conceptual point of view, this is probably due to the fact that some respondents related hydroelectric power production, the second constitutive item for 'economic water values', more with personal consumption than with its economic value creation. This added some 'noise' to the data, caused by the multidimensionality of that item. However, the loading of 0.428 is still relatively high, thus we do keep 'economic water values' as a separate latent variable in our analysis.

Table 3: Rotated pattern matrix of EFA with assigned values

\begin{tabular}{|c|c|c|c|}
\hline \multirow[t]{2}{*}{ ASSIGNED VALUE ITEMS } & \multicolumn{3}{|c|}{ EXTRACTED FACTORS } \\
\hline & $\begin{array}{l}1 \text { (Ecological } \\
\text { water values) }\end{array}$ & $\begin{array}{c}2 \text { (Cultural } \\
\text { water values) }\end{array}$ & $\begin{array}{l}3 \text { (Economic } \\
\text { water values) }\end{array}$ \\
\hline $\begin{array}{l}\text { Relative importance of traditional } \\
\text { lifestyles, including artisanal fishing }\end{array}$ & .026 & .540 & .046 \\
\hline $\begin{array}{l}\text { Relative importance of the economy } \\
\text { and agriculture }\end{array}$ & .032 & .104 & .428 \\
\hline $\begin{array}{l}\text { Relative importance of nature and the } \\
\text { Pantanal }\end{array}$ & .604 & .013 & .051 \\
\hline $\begin{array}{l}\text { Relative importance of cultural values, } \\
\text { including traditional festivities }\end{array}$ & -.025 & .663 & -.038 \\
\hline $\begin{array}{l}\text { Relative importance of hydroelectric } \\
\text { power production }\end{array}$ & -.028 & -.058 & .568 \\
\hline $\begin{array}{l}\text { Relative importance of wildlife, e.g. } \\
\text { jaguars, birds, caimans }\end{array}$ & .652 & -.015 & -.052 \\
\hline
\end{tabular}

The results of the EFA of governance-related values were reported in Schulz (2018) and suggested the existence of three separate governance-related values, namely democratic, economic, and scientific governance-related values.

\section{Supplementary material S5: Description of the waterway in the survey}

To elicit people's opinions on the construction of the Paraguay-Paraná Waterway, they were first asked the following question:

"Now I would like to know your opinion about a water-related project. Have you heard already about the proposal to build a waterway through the Pantanal, on the Paraguay River, beginning near Cáceres?" (Y/N)

Then some background was given to ensure that respondents had sufficient knowledge to given an informed opinion: 
"The waterway will use the river for the transport of products with commercial vessels. The main objective of the waterway is to facilitate the export of soybeans, corn and other products, because it is cheaper to transport them on the river rather than on the highways to the ports on the Brazilian coast. Once the waterway is built, it will benefit the agribusiness sector and for that reason it is likely that agriculture will grow more.

But there are also concerns that the waterway could have a negative impact on the Pantanal. Scientists expect that fish numbers will decrease, that the natural environment will be damaged and that it will be more difficult for the local fishermen and small-scale farmers to sustain themselves.

Now, imagine that the government would do a referendum about the waterway. Would you vote in favour or against the construction of the waterway?" (FOR/AGAINST/REFUSED/DON'T KNOW)

Supplementary material S6: Confirmatory factor analyses (CFAs) of fundamental values, governancerelated values and assigned values

Confirmatory factor analyses (CFA) were conducted to test the quality of each of the three measurement models for assigned values, governance-related values, and fundamental values, respectively and to establish construct validity, using the lavaan package in $R$ (v. 0.5-23.1097). Missing cases were deleted listwise, which affected no more than $3.94 \%$ of overall observations at any point, which is below the 5\% threshold that Garson (2015) recommends for using listwise deletion. Rates of missing values could overall be kept quite low as interviewers had been trained in probing techniques, such as reassuring the respondent that there were no right or wrong answers when noticing that they were hesitant to pick an answer. Having ordinal data, we used polychoric correlations for this analysis, which assume that an underlying continuous variable is measured in a number of discrete categories (Garson 2015); a plausible assumption for people's values. Furthermore, we applied diagonally weighted least squares (DWLS) as a model estimation method, which is appropriate for categorical (ordinal) data with sample sizes of around 1000 (Bandalos 2014).

To evaluate model fit, we relied on a combination of absolute and incremental fit indexes (RMSEA, SRMR, CFI, TLI, and model $\chi^{2}$ significance/ $p$ value) as is widely recommended in the CFA and SEM literature (Brown 2006; Garson 2015; Kline 2011). Model $\chi^{2}$ is sensitive to sample size and it has been suggested that it rejects most models with sample sizes above 200. This has led many researchers to ignore it when other fit measures indicate good fit (Garson 2015; Hooper et al. 2008), although the issue remains controversial (Barrett 2007; Kline 2011). RMSEA is almost universally cited in CFA and SEM studies and generally considered to be acceptable at 0.06 or lower (Hu \& Bentler 1999). Hooper et al. (2008) state that it is sensitive to the number of estimated parameters in the model, and favours more parsimonious models, one of the main reasons for its high popularity. Yet Mulaik (2009) finds no association between RMSEA and model parsimony, so this claim remains disputed. Kline (2011) recommends reporting RMSEA with a $90 \%$ confidence interval. SRMR is recommended to fall below a cut-off value of 0.08 ( $\mathrm{Hu} \&$ Bentler 1999); the lower it is, the lower the covariance residuals, i.e. the differences between the observed and predicted covariances (Kline 2011). CFI and TLI should both be 0.95 or higher (Hu \& Bentler 1999), indicating that $95 \%$ of the covariation in the data can be reproduced by the specified model as opposed to a null model in which indicator variables are uncorrelated (Garson 2015). CFI and TLI are not affected by sample size, and TLI additionally penalises for parsimony. Generally, we also aim to discuss all models from a substantive perspective, i.e. discussing their actual meaning, instead of relying on purely data-driven strategies, such as the application of modification indexes, which is typically discouraged in the literature. 
A CFA of the fundamental value items indicates acceptable model fit overall (see Table 4), although model $\chi^{2}$ is significant, possibly due to the large sample size. However, problems can be found with the measurement of the fundamental value 'stimulation'. Item 'stimulation 2 ' is not significant with a p-value of 0.089 and the factor loading of 'stimulation 1' on stimulation is unusually high (1.315). The first item aimed to measure respondents' appreciation of surprises and the second item measured their willingness to take risks. Evidently, the risk-seeking item was not suitable for the local context in Mato Grosso, as risk-seeking in an environment with very high levels of crime and a society in deep political and economic crisis was perceived to be ironic (a large proportion of respondents literally laughed at the question). It thus understandably did not form a common latent variable with an appreciation of surprises. This fundamental value was thus excluded from the analysis altogether. We can find further issues when studying standardised covariances (i.e. correlations) of various values: the fundamental value 'tradition' has two correlations with values beyond 1 (with universalism and conformity). This again indicates problems with its measurement, although finding a substantive explanation is less straightforward than in the case of the fundamental value 'stimulation'. Notably, there is also a very high correlation between universalism and benevolence, suggesting that these could have been modelled as one latent variable rather than two. As noted in the main manuscript, the Schwartz value framework contains four meta-categories or higher-order dimensions, and universalism and benevolence fall jointly into the meta-category of self-transcendence, although Schwartz and Boehnke (2004) note that alternative meta-categorisations are possible.

Table 4: CFA fundamental values

\begin{tabular}{lllllllll}
\hline $\begin{array}{l}\mathbf{N} \\
\text { (used) }\end{array}$ & $\boldsymbol{\chi}^{2}$ & $\begin{array}{l}\text { df (degrees of } \\
\text { freedom) }\end{array}$ & $\begin{array}{l}\text { P-value } \\
\left(\chi^{2}\right)\end{array}$ & CFI & TLI & RMSEA & $\begin{array}{l}\text { 90\% conf. int. } \\
\text { (RMSEA) }\end{array}$ & SRMR \\
\hline 1051 & 641.897 & 144 & 0.000 & 0.968 & 0.953 & 0.057 & $0.053,0.062$ & 0.053
\end{tabular}

\section{LATENT VARIABLES}

\begin{tabular}{|c|c|c|c|c|c|c|}
\hline \multirow[t]{3}{*}{ Universalism } & $\begin{array}{l}\text { Item/indicator } \\
\text { universalism } 1\end{array}$ & $\begin{array}{c}\text { Estimate } \\
1 \text { (fixed) }\end{array}$ & Std. err. & z-value & $P(>|z|)$ & $\begin{array}{c}\text { Std. est. } \\
0.566\end{array}$ \\
\hline & universalism 2 & 0.982 & 0.062 & 15.836 & 0.000 & 0.556 \\
\hline & universalism 3 & 1.281 & 0.069 & 18.679 & 0.000 & 0.725 \\
\hline \multirow[t]{2}{*}{ Benevolence } & benevolence 1 & 1 (fixed) & & & & 0.723 \\
\hline & benevolence 2 & 0.995 & 0.040 & 24.682 & 0.000 & 0.719 \\
\hline \multirow[t]{2}{*}{ Conformity } & conformity 1 & 1 (fixed) & & & & 0.388 \\
\hline & conformity 2 & 1.240 & 0.133 & 9.333 & 0.000 & 0.481 \\
\hline \multirow[t]{2}{*}{ Tradition } & tradition 1 & 1 (fixed) & & & & 0.656 \\
\hline & tradition 2 & 0.750 & 0.038 & 19.649 & 0.000 & 0.492 \\
\hline \multirow[t]{2}{*}{ Security } & security 1 & 1 (fixed) & & & & 0.664 \\
\hline & security 2 & 0.964 & 0.049 & 19.574 & 0.000 & 0.640 \\
\hline \multirow[t]{2}{*}{ Power } & power 1 & 1 (fixed) & & & & 0.477 \\
\hline & power 2 & 1.052 & 0.129 & 8.159 & 0.000 & 0.501 \\
\hline \multirow[t]{2}{*}{ Achievement } & achievement 1 & 1 (fixed) & & & & 0.644 \\
\hline & achievement 2 & 1.249 & 0.083 & 14.976 & 0.000 & 0.804 \\
\hline \multirow[t]{2}{*}{ Hedonism } & hedonism 1 & 1 (fixed) & & & & 0.672 \\
\hline & hedonism 2 & 0.837 & 0.055 & 15.342 & 0.000 & 0.563 \\
\hline \multirow[t]{2}{*}{ Stimulation } & stimulation 1 & 1 (fixed) & & & & 1.315 \\
\hline & stimulation 2 & 0.120 & 0.071 & 1.702 & 0.089 & 0.158 \\
\hline \multirow[t]{2}{*}{ Self-direction } & self-direction 1 & 1 (fixed) & & & & 0.560 \\
\hline & self-direction 2 & 0.706 & 0.079 & 8.955 & 0.000 & 0.395 \\
\hline
\end{tabular}




\begin{tabular}{|c|c|c|c|c|c|c|}
\hline Latent variable 1 & Latent variable 2 & Estimate & Std. err. & z-value & $\mathrm{P}(>|z|)$ & Std. est. \\
\hline \multirow[t]{9}{*}{ Universalism } & Benevolence & 0.397 & 0.024 & 16.829 & 0.000 & 0.970 \\
\hline & Conformity & 0.142 & 0.018 & 8.000 & 0.000 & 0.645 \\
\hline & Tradition & 0.403 & 0.024 & 16.516 & 0.000 & 1.086 \\
\hline & Security & 0.318 & 0.023 & 13.935 & 0.000 & 0.844 \\
\hline & Power & -0.070 & 0.017 & -4.047 & 0.000 & -0.260 \\
\hline & Achievement & 0.121 & 0.018 & 6.862 & 0.000 & 0.331 \\
\hline & Hedonism & 0.234 & 0.020 & 11.555 & 0.000 & 0.616 \\
\hline & Stimulation & 0.183 & 0.023 & 8.053 & 0.000 & 0.245 \\
\hline & Self-direction & 0.204 & 0.022 & 9.176 & 0.000 & 0.644 \\
\hline \multirow[t]{8}{*}{ Benevolence } & Conformity & 0.186 & 0.023 & 8.039 & 0.000 & 0.664 \\
\hline & Tradition & 0.466 & 0.021 & 22.048 & 0.000 & 0.984 \\
\hline & Security & 0.381 & 0.022 & 17.602 & 0.000 & 0.794 \\
\hline & Power & -0.021 & 0.022 & -0.956 & 0.339 & -0.060 \\
\hline & Achievement & 0.146 & 0.020 & 7.171 & 0.000 & 0.313 \\
\hline & Hedonism & 0.324 & 0.022 & 14.422 & 0.000 & 0.666 \\
\hline & Stimulation & 0.190 & 0.026 & 7.192 & 0.000 & 0.200 \\
\hline & Self-direction & 0.316 & 0.025 & 12.839 & 0.000 & 0.781 \\
\hline \multirow[t]{7}{*}{ Conformity } & Tradition & 0.264 & 0.026 & 10.176 & 0.000 & 1.039 \\
\hline & Security & 0.205 & 0.022 & 9.231 & 0.000 & 0.796 \\
\hline & Power & 0.047 & 0.017 & 2.766 & 0.006 & 0.253 \\
\hline & Achievement & 0.099 & 0.016 & 6.056 & 0.000 & 0.397 \\
\hline & Hedonism & 0.087 & 0.019 & 4.622 & 0.000 & 0.334 \\
\hline & Stimulation & 0.048 & 0.020 & 2.355 & 0.019 & 0.094 \\
\hline & Self-direction & 0.088 & 0.019 & 4.518 & 0.000 & 0.403 \\
\hline \multirow[t]{6}{*}{ Tradition } & Security & 0.386 & 0.023 & 16.797 & 0.000 & 0.886 \\
\hline & Power & -0.072 & 0.023 & -3.169 & 0.002 & -0.232 \\
\hline & Achievement & 0.186 & 0.022 & 8.573 & 0.000 & 0.440 \\
\hline & Hedonism & 0.292 & 0.023 & 12.763 & 0.000 & 0.663 \\
\hline & Stimulation & 0.179 & 0.029 & 6.215 & 0.000 & 0.208 \\
\hline & Self-direction & 0.236 & 0.025 & 9.639 & 0.000 & 0.644 \\
\hline \multirow[t]{5}{*}{ Security } & Power & 0.001 & 0.021 & 0.054 & 0.957 & 0.004 \\
\hline & Achievement & 0.203 & 0.022 & 9.365 & 0.000 & 0.475 \\
\hline & Hedonism & 0.265 & 0.022 & 11.863 & 0.000 & 0.594 \\
\hline & Stimulation & 0.212 & 0.026 & 8.175 & 0.000 & 0.243 \\
\hline & Self-direction & 0.219 & 0.024 & 9.267 & 0.000 & 0.588 \\
\hline \multirow[t]{4}{*}{ Power } & Achievement & 0.178 & 0.023 & 7.597 & 0.000 & 0.581 \\
\hline & Hedonism & 0.133 & 0.024 & 5.664 & 0.000 & 0.417 \\
\hline & Stimulation & 0.095 & 0.025 & 3.787 & 0.000 & 0.152 \\
\hline & Self-direction & 0.065 & 0.022 & 2.927 & 0.003 & 0.244 \\
\hline \multirow[t]{3}{*}{ Achievement } & Hedonism & 0.282 & 0.023 & 12.187 & 0.000 & 0.651 \\
\hline & Stimulation & 0.262 & 0.024 & 10.816 & 0.000 & 0.310 \\
\hline & Self-direction & 0.148 & 0.022 & 6.813 & 0.000 & 0.410 \\
\hline \multirow[t]{2}{*}{ Hedonism } & Stimulation & 0.358 & 0.025 & 14.314 & 0.000 & 0.405 \\
\hline & Self-direction & 0.270 & 0.026 & 10.542 & 0.000 & 0.717 \\
\hline Stimulation & Self-direction & 0.259 & 0.027 & 9.528 & 0.000 & 0.351 \\
\hline
\end{tabular}

Not least because many researchers recommend measuring latent variables with three or more indicators (Brown 2006; Kline 2011), we thus decided to measure fundamental values in the four higher-order dimensions of self-enhancement, self-transcendence, openness to change, and 
conservation. A second CFA (excluding 'stimulation') with these produced similar, slightly improved model fit statistics (see Table 5). Again, however, we find issues with individual items. Now, 'power 1' and 'power 2' display very low factor loadings below 0.3 on self-enhancement; 'conformity 1 ' and 'conformity 2' possess factor loadings below 0.4 on conservation; and 'self-direction 2' loads below 0.4 on openness to change. We thus exclude these items from the analysis as well, using 0.4 as our cut-off point in accordance with Stevens (2009). This means that indicators used share at least $15 \%$ of their variance with the construct.

Item 'power 1' (which is also the only item not to be significant with a p-value of 0.000 ) related to people's desire to be wealthy, which culturally would have been inappropriate to admit to a stranger. ${ }^{8}$ The low loading with self-enhancement can thus be explained, as other forms of self-enhancement (e.g. the 'achievement' items) would not have been controversial from a cultural point of view. The low loadings for conformity might be related to the ambiguity of the items. Some respondents cited that "behaving properly" and "avoid doing what people would say is wrong" (sentences 1 and 2 of item 'conformity 2') were contradictory as 'behaving properly' might involve not listening to other people's opinions. It is not clear whether other applications of the Schwartz Portrait Value Questionnaire faced the same issue; however, this item's formulation should indeed be reconsidered generally, beyond our individual study. 'Self-direction 2' cited "not depending on others" as a personal principle to measure self-determination; again some respondents critically remarked that this is an unrealistic formulation as even the most independent person depends on others in some way or another. Yet we can only speculate whether that is the reason for this item's low factor loading on openness to change.

Table 5: CFA fundamental values (four dimensions)

\begin{tabular}{lllllllll}
\hline $\begin{array}{l}\mathbf{N} \\
\text { (used) }\end{array}$ & $\chi^{2}$ & $\begin{array}{l}\text { df (degrees of } \\
\text { freedom) }\end{array}$ & $\begin{array}{l}\text { P-value } \\
\left(\chi^{2}\right)\end{array}$ & CFI & TLI & RMSEA & $\begin{array}{l}\text { 90\% conf. int. } \\
\text { (RMSEA) }\end{array}$ & SRMR \\
\hline 1053 & 581.107 & 146 & 0.000 & 0.969 & 0.964 & 0.053 & $0.049,0.058$ & 0.055
\end{tabular}

\section{LATENT VARIABLES}

\begin{tabular}{llccccc}
\hline Latent variable & Item/indicator & Estimate & Std. err. & z-value & $\mathbf{P}(>|\mathbf{z}|)$ & Std. est. \\
Self-transcendence & universalism 1 & 1 (fixed) & & & & 0.565 \\
& universalism 2 & 0.983 & 0.063 & 15.692 & 0.000 & 0.556 \\
& universalism 3 & 1.282 & 0.070 & 18.357 & 0.000 & 0.725 \\
& benevolence 1 & 1.258 & 0.071 & 17.703 & 0.000 & 0.711 \\
& benevolence 2 & 1.256 & 0.070 & 17.875 & 0.000 & 0.710 \\
Self-enhancement & achievement 1 & 1 (fixed) & & & & 0.643 \\
& achievement 2 & 1.300 & 0.100 & 13.049 & 0.000 & 0.836 \\
& power 1 & 0.167 & 0.066 & 2.530 & 0.011 & 0.107 \\
Openness to change & power 2 & 0.458 & 0.057 & 8.064 & 0.000 & 0.295 \\
& hedonism 1 & 1 (fixed) & & & & 0.643 \\
& hedonism 2 & 0.783 & 0.056 & 14.102 & 0.000 & 0.504 \\
Conservation & self-direction 1 & 0.755 & 0.057 & 13.267 & 0.000 & 0.486 \\
& self-direction 2 & 0.560 & 0.056 & 10.080 & 0.000 & 0.360 \\
& security 1 & 1 (fixed) & & & & 0.608 \\
& security 2 & 0.980 & 0.049 & 20.133 & 0.000 & 0.596 \\
& tradition 1 & 1.166 & 0.053 & 22.17 & 0.000 & 0.709 \\
& tradition 2 & 0.867 & 0.050 & 17.389 & 0.000 & 0.527
\end{tabular}

\footnotetext{
${ }^{8}$ And while we did not perform a statistical test to prove this, we found that independent of their income, most respondents would be quick to dismiss any personal interest in wealth, from the poorest to the richest.
} 


$\begin{array}{llllll}\text { conformity 1 } & 0.524 & 0.051 & 10.272 & 0.000 & 0.318 \\ \text { conformity 2 } & 0.648 & 0.050 & 12.958 & 0.000 & 0.394\end{array}$

\begin{tabular}{llccccc} 
COVARIANCES & & & & & \\
\hline Latent variable 1 & Latent variable 2 & Estimate & Std. err. & z-value & $\mathbf{P}(>|\mathbf{z}|)$ & Std. est. \\
Self-transcendence & Self-enhancement & 0.105 & 0.015 & 6.882 & 0.000 & 0.288 \\
& Openness to change & 0.268 & 0.020 & 13.501 & 0.000 & 0.736 \\
& Conservation & 0.317 & 0.021 & 14.935 & 0.000 & 0.924 \\
Self-enhancement & Openness to change & 0.263 & 0.023 & 11.435 & 0.000 & 0.635 \\
& Conservation & 0.170 & 0.018 & 9.353 & 0.000 & 0.435 \\
Openness to change & Conservation & 0.259 & 0.019 & 13.509 & 0.000 & 0.661 \\
\hline
\end{tabular}

The third (and final) CFA of fundamental values thus consisted of a reduced set of fundamental value items, having excluded potential sources of measurement error and 'noise'. Model fit statistics are all remarkably better, except model $\chi^{2}$ significance, again likely due to large sample size (see Table 6). We see a very high correlation between self-transcendence and conservation (0.962), which is a bit concerning even though these are neighbouring dimensions. Yet, similar results have been reported before, e.g. in Glenk and Fischer's (2010) SEM study. However, we decided to keep these two constructs separate as from a conceptual point of view, they are not identical.

Table 6: CFA fundamental values (four dimensions) - final version

\begin{tabular}{lllllllll}
\hline $\begin{array}{l}\mathbf{N} \\
\text { (used) }\end{array}$ & $\chi^{2}$ & $\begin{array}{l}\text { df (degrees of } \\
\text { freedom) }\end{array}$ & $\begin{array}{l}\text { P-value } \\
\left(\chi^{2}\right)\end{array}$ & CFI & TLI & RMSEA & $\begin{array}{l}\text { 90\% conf. int. } \\
\text { (RMSEA) }\end{array}$ & SRMR \\
\hline 1059 & 178.588 & 71 & 0.000 & 0.991 & 0.989 & 0.038 & $0.031,0.045$ & 0.037
\end{tabular}

LATENT VARIABLES

\begin{tabular}{llccccc}
\hline Latent variable & Item/indicator & Estimate & Std. err. & z-value & $\mathbf{P}(>|\mathbf{z}|)$ & $\begin{array}{c}\text { Std. est. } \\
\text { Self-transcendence }\end{array}$ \\
& universalism 1 & 1 (fixed) & & & & 0.577 \\
& universalism 2 & 0.974 & 0.059 & 16.472 & 0.000 & 0.562 \\
& universalism 3 & 1.263 & 0.065 & 19.413 & 0.000 & 0.729 \\
& benevolence 1 & 1.226 & 0.067 & 18.375 & 0.000 & 0.707 \\
& benevolence 2 & 1.228 & 0.066 & 18.563 & 0.000 & 0.708 \\
Self-enhancement & achievement 1 & 1 (fixed) & & & & 0.647 \\
& achievement 2 & 1.234 & 0.099 & 12.412 & 0.000 & 0.798 \\
Openness to change & hedonism 1 & 1 (fixed) & & & & 0.647 \\
& hedonism 2 & 0.795 & 0.057 & 13.889 & 0.000 & 0.515 \\
Conservation & self-direction 1 & 0.739 & 0.057 & 12.997 & 0.000 & 0.478 \\
& security 1 & 1 (fixed) & & & & 0.587 \\
& security 2 & 0.976 & 0.049 & 20.039 & 0.000 & 0.573 \\
& tradition 1 & 1.171 & 0.054 & 21.575 & 0.000 & 0.688 \\
& tradition 2 & 0.870 & 0.052 & 16.807 & 0.000 & 0.511 \\
COVARIANCES & & & & & & \\
\hline Latent variable 1 & Latent variable 2 & Estimate & Std. err. & z-value & $\mathbf{P}(>|\mathbf{z}|)$ & Std. est. \\
Self-transcendence & Self-enhancement & 0.125 & 0.017 & 7.546 & 0.000 & 0.335 \\
& Openness to change & 0.270 & 0.020 & 13.594 & 0.000 & 0.722 \\
Self-enhancement & Conservation & 0.326 & 0.021 & 15.291 & 0.000 & 0.962 \\
& Openness to change & 0.268 & 0.024 & 11.231 & 0.000 & 0.640 \\
Openness to change & Conservation & 0.183 & 0.019 & 9.574 & 0.000 & 0.482 \\
\hline & Conservation & 0.269 & 0.019 & 13.842 & 0.000 & 0.708 \\
\hline
\end{tabular}


Following the CFA of fundamental values, we then proceeded to a CFA of the three governance-related values identified in the EFA earlier. The findings were reported in Schulz (2018) and largely confirmed the structure found in the previous EFA.

Similarly the CFA of the three assigned values indicates no need to modify this specific part of our measurement model (see Table 7). Considering the low number of six degrees of freedom in both CFAs, it is in fact remarkable that our RMSEA values are so close to 0, given that Kenny et al. (2015) found that they are often falsely inflated in models with low numbers of degrees of freedom, even with large sample sizes.

Table 7: CFA assigned values

\begin{tabular}{lllllllll}
\hline $\begin{array}{l}\mathbf{N} \\
\text { (used) }\end{array}$ & $\chi^{2}$ & $\begin{array}{l}\text { df (degrees of } \\
\text { freedom) }\end{array}$ & $\begin{array}{l}\text { P-value } \\
\left(\chi^{2}\right)\end{array}$ & CFI & TLI & RMSEA & $\begin{array}{l}\text { 90\% conf. int. } \\
\text { (RMSEA) }\end{array}$ & SRMR \\
\hline 1057 & 4.245 & 6 & 0.644 & 1.000 & 1.006 & 0.000 & $0.000,0.033$ & 0.026
\end{tabular}

LATENT VARIABLES

\begin{tabular}{|c|c|c|c|c|c|c|}
\hline Latent variable & Item/indicator & Estimate & Std. err. & z-value & $P(>|z|)$ & Std. est. \\
\hline Cultural water & Traditional lifestyles & 1 (fixed) & & & & 0.664 \\
\hline values & Traditional festivities & 0.986 & 0.106 & 9.261 & 0.000 & 0.654 \\
\hline Economic water & Agriculture & 1 (fixed) & & & & 0.749 \\
\hline values & Hydroelectric power & 0.615 & 0.120 & 5.143 & 0.000 & 0.461 \\
\hline Ecological water & Pantanal's nature & 1 (fixed) & & & & 0.850 \\
\hline values & Wildlife & 0.770 & 0.140 & 5.481 & 0.000 & 0.654 \\
\hline \multicolumn{7}{|l|}{ COVARIANCES } \\
\hline Latent variable 1 & ter & Estir & Std. err. & z-value & $P(>|z|)$ & Std. est. \\
\hline Cultural water & values & 0.2 & & 8.225 & 0.000 & 0.568 \\
\hline values & Ecolo & & & & 0.000 & 0.526 \\
\hline Economic w. values & Ecological w. values & 0.148 & 0.043 & 3.435 & 0.001 & 0.232 \\
\hline
\end{tabular}

Finally, it should be noted that the latent variables "conservation", "openness to change", and "scientific governance" were not included in our final structural equation model described in the main manuscript. While their inclusion would in principle have been possible, we eventually decided to create a more parsimonious model that included the more relevant and less ambiguous fundamental and governance-related values only. Self-enhancement and self-transcendence were retained in the model, given that plenty of previous psychological research has shown that these dimensions relate better to environmental issues than the dimensions of conservation and openness to change (see e.g. Schultz et al. 2005; Steg \& de Groot 2012). Scientific governance was judged too ambiguous in the present research context, given that the constituting item on sustainability was universally claimed by all interviewees in the earlier study by Schulz et al. (2017), limiting its usefulness to distinguish between various value landscapes.

\section{References}

Bandalos, D.L. (2014): Relative Performance of Categorical Diagonally Weighted Least Squares and Robust Maximum Likelihood Estimation, in: Structural Equation Modeling, vol. 21: 102-116. 
Bandalos, D.L. \& Boehm-Kaufman, M.R. (2009): Four Common Misconceptions in Exploratory Factor Analysis, in: Lance, C.E. \& Vandenberg, R.J. (eds.): Statistical and Methodological Myths and Urban Legends: Doctrine, Verity and Fable in the Organizational and Social Sciences, New York \& Hove, UK: Routledge, 61-87.

Barrett, P. (2007): Structural equation modelling: adjudging model fit, in: Personality and Individual Differences, vol. 42: 815-824.

Brown, T.A. (2006): Confirmatory Factor Analysis for Applied Research, New York \& London: The Guildford Press.

Costello, A.B. \& Osborne, J.W. (2005): Best Practices in Exploratory Factor Analysis: Four Recommendations for Getting the Most From Your Analysis, in: Practical Assessment, Research \& Evaluation, vol. 10(7).

de Winter, J.C.F. \& Dodou, D. (2012): Factor recovery by principal axis factoring and maximum likelihood factor analysis as a function of factor pattern and sample size, in: Journal of Applied Statistics, vol. 39(4): 695-710.

Fabrigar, L.R., Wegener, D.T., MacCallum, R.C., \& Strahan, E.J. (1999): Evaluating the Use of Exploratory Factor Analysis in Psychological Research, in: Psychological Methods, vol. 4(3): 272-299.

Garson, G.D. (2015): Structural Equation Modeling, Asheboro, NC: Statistical Associates Publishers.

Glenk, K. \& Fischer, A. (2010): Insurance, prevention or just wait and see? Public preferences for water management strategies in the context of climate change, in: Ecological Economics, vol. 69(11): 2279-2291.

Hooper, D., Coughlan, J., \& Mullen, M.R. (2008): Structural Equation Modelling: Guidelines for Determining Model Fit, in: The Electronic Journal of Business Research Methods, vol. 6(1): 53-60.

Hu, L. \& Bentler, P.M. (1999): Cutoff Criteria for Fit Indexes in Covariance Structure Analysis:

Conventional Criteria Versus New Alternatives, in: Structural Equation Modeling, vol. 6(1): 1-55.

Kenny, D.A., Kaniskan, B., \& McCoach, D.B. (2015): The Performance of RMSEA in Models with Small Degrees of Freedom, in: Sociological Methods \& Research, vol. 44(3): 486-507.

Kline, R.B. (2011): Principles and Practice of Structural Equation Modeling, $3^{\text {rd }}$ ed., New York: The Guilford Press.

Mulaik, S.A. (2009): Linear Causal Modeling with Structural Equations, Boca Raton, FL: CRC Press.

Peterson, R.A. (2000): A Meta-Analysis of Variance Accounted for and Factor Loadings in Exploratory Factor Analysis, in: Marketing Letters, vol. 11(3): 261-275.

Schultz, P.W., Gouveia, V.V., Cameron, L.D., Tankha, G., Schmuck, P., \& Franěk, M. (2005): Values and their Relationship to Environmental Concern and Conservation Behavior, in: Journal of CrossCultural Psychology, vol. 36(4): 457-475.

Schulz, C. (2018): Governance-related values as dimensions of good water governance, in: Wiley Interdisciplinary Reviews: Water, e1322, doi:10.1002/wat2.1322.

Schulz, C., Martin-Ortega, J., loris, A.A.R., \& Glenk, K. (2017): Applying a 'Value Landscapes Approach' to Conflicts in Water Governance: The Case of the Paraguay-Paraná Waterway, in: Ecological Economics, vol. 138: 47-55. 
Schwartz, S. (2001): A Proposal for Measuring Value Orientations across Nations, in: European Social Survey (ed.): European Social Survey Core Questionnaire Development, London, UK: City University London, 259-319.

Schwartz, S.H. \& Boehnke, K. (2004): Evaluating the structure of human values with confirmatory factor analysis, in: Journal of Research in Personality, vol. 38: 230-255.

Schwartz, S.H., Cieciuch, J., Vecchione, M., Davidov, E., Fischer, R., Beierlein, C., Ramos, A., Verkasalo, M., Lönnqvist, J., Demirutku, K., Dirilen-Gümüş, Ö., \& Konty, M. (2012): Refining the Theory of Basic Individual Values, in: Journal of Personality and Social Psychology, vol. 103(4): 663688.

Steg, L. \& de Groot, J.I.M. (2012): Environmental Values, in: Clayton, S.D. (ed.): The Oxford Handbook of Environmental and Conservation Psychology, New York, NY, USA: Oxford University Press, 81-92.

Stevens, J.P. (2009): Applied multivariate statistics for the social sciences, $5^{\text {th }}$ ed., New York \& Hove, UK: Routledge.

van der Eijk, C. \& Rose, J. (2015): Risky Business: Factor Analysis of Survey Data - Assessing the Probability of Incorrect Dimensionalisation, in: PLOS ONE, vol. 10(3): e0118900. 